DOI: http://dx.doi.org/10.21276/ap.2020.9.2.3

Annals of Phytomedicine: An International Journal

http://www.ukaazpublications.com/publications/index.php

\title{
Micronutrients and phytochemicals against COVID-19: Mechanism and molecular targets
}

\author{
Yuva Bellik*, Mostapha Bachir-Bey*, Wided Fatmi, Mokhtaria Kouidri**, Yasmina Souagui and Sidi Mohammed Ammar Selles** \\ Faculty of Life and Nature Sciences, Mohamed El Bachir El Ibrahimi University, Bordj Bou Arreridj, 34000, Algeria \\ *Laboratory of applied Biochemistry, Faculty of Life and Nature Sciences, Abderrahmane Mira University, Bejaia, 06000, Algeria \\ **Institute of Veterinary Sciences, University of Tiaret, Tiaret, 14000, Algeria
}

\section{Article Info}

\section{Article history}

Received 2 September 2020

Revised 24 October 2020

Accepted 26 October 2020

Published online 30 December 2020

\section{Keywords}

COVID-19

Plants

Micronutrients

Immune response

Antiviral activity

\begin{abstract}
The recent emergence of coronavirus disease (COVID-19) caused a continuous threat to humans. Currently, the race for COVID-19 vaccines through laboratory tests has generated more than 180 vaccine candidates, however the scientific community remains skeptical regarding their administration for the general public. Plants are a rich source of medicinally active constituents that have long been used over the years in aromatherapy and phytomedicine due to their biological properties including antiviral, antimicrobial, antioxidant, anticancer, immunomodulatory and anti-inflammatory effects. Likewise, evidence from in vitro studies and controlled clinical trials highlighted the health benefits of some vitamins, micronutrients, and trace elements in viral infections. The purpose of this article is to describe the current knowledge about micronutrients and phytochemicals that can help prevent and inhibit COVID-19.
\end{abstract}

\section{Introduction}

The world is currently facing a pneumonia outbreak caused by the new coronavirus (SARS-CoV-2). The disease can be asymptomatic or present mild affection of the upper respiratory tract (Khan et al., 2020; Subbarao and Mahanty, 2020). Patients with the most severe forms of COVID-19 are often elderly and affected by acute respiratory distress syndrome (Liu et al., 2020; Perrota et al., 2020). SARS-CoV-2 mainly attacks the lower respiratory system to cause viral pneumonia, but it may also affect the gastrointestinal system, heart, kidney, liver, and central nervous system leading to multiple organ failure (Zhu et al., 2020). Several combined therapies have been used to treat complications associated to virus infection (Fernandes et al., 2020; Sarkar et al., 2020), and more than 180 vaccines are currently in development (Krammer, 2020), however, until now, there has no specific and effective drug or vaccine to treat COVID-19.

Plants provide a valuable and powerful resource of phytochemicals components including phenols, flavonoids, volatile oil, etc., displaying antiviral properties (Haslberger et al., 2020 ; Mani et al., 2020). Existing evidences suggest that the consumption of plant-derived regiments can strengthen the immune system and help to fight against COVID-19 (Chojnacka et al., 2020; Fernández-Quintela et al.,

Corresponding author: Dr. Yuva Bellik

Associate Professor, Faculty of Life and Nature Sciences, Mohamed El Bachir El Ibrahimi University, Bordj Bou Arreridj, 34000, Algeria E-mail: y.bellik@univ-bba.dz

Tel.: +213-657259922

Copyright (c) 2020 Ukaaz Publications. All rights reserved.

Email: ukaaz@yahoo.com; Website: www.ukaazpublications.com
2020). Naturally occurring phytochemicals have the advantages of low toxicity and high efficiency to inhibit virus proliferation and can also regulate the host immune response (Cowan, 1999). Likewise, adequate intake of vitamins A, B, C, D, E, zinc, and iron is essential to maintain a strong immune system (Jayawardena et al., 2020).

This review aims to present an overview of coronavirus morphology, biology, and pathogenesis with a particular focus on mechanism of action of natural bioactive compounds including vitamins, trace elements, flavonoids, phenolic acids, and alkaloids against SARS-CoV-2 infection and replication and their role in enhancing the immunity. These natural molecules were selected based on their effectiveness against SARS-CoV-2 infection as well as other RNA viruses including SARS-CoV, MERS-CoV, and influenza.

\section{Mechanism of virus infection}

Coronaviruses (CoVs) are positive-stranded RNA viruses with a crown-like appearance under an electron microscope due to the presence of spike glycoproteins on the envelope (Cascella et al., 2020). Coronaviruses belong to the family Coronaviridae and are divided into alpha $(\alpha-\mathrm{CoV})$, beta $(\beta-\mathrm{CoV})$, gamma $(\gamma-\mathrm{CoV})$, and delta $(\delta-\mathrm{CoV})$ coronaviruses. The alpha and beta coronaviruses can infect mammals, the viruses infecting humans are genetically similar to $\beta-\mathrm{CoV}$ genus (Letko et al., 2020). Structural analysis of SARS-CoV-2 shows the virus as cylindrical with four specified proteins encoded by the minor sections of the genome (Song et al., 2018). These include membrane (M) protein, spike (S) protein, envelope (E) protein, and nucleocapsid (N) protein (Figure 1). The protein $(\mathrm{S})$ is the greatest structure and makes distinct spikes on the virus surface (Suhail et al., 2020). 


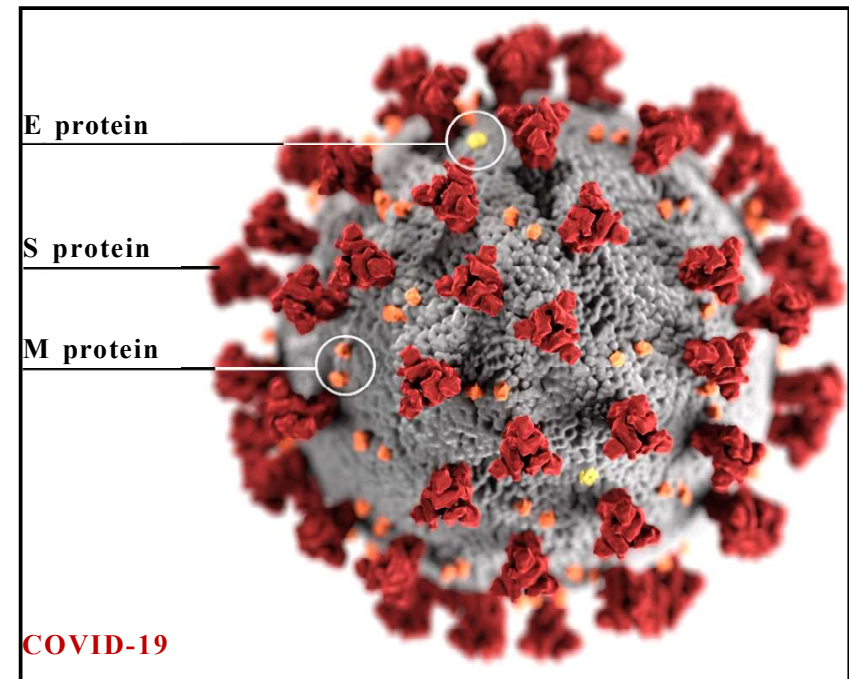

Figure 1: Coronavirus virion structure

Corona virus - Photo credit: CDC/Alissa Eckert, MS; Dan Higgins, MAMS (Source: Khan et al., 2020: The COVID-19 pandemic: A scoping review.)

\subsection{Virus attachment and entry}

The major place of entry for viruses into the body is the respiratory tract (Subbarao and Mahanty, 2020). Infection is initiated by interaction of the viral particle with specific proteins on the cell surface. After initial binding with receptor, enveloped virus fuse its envelope with host cell membrane to deliver its nucleocapsid to the target cell. The spike (S) protein plays a role in entry by mediating receptor binding and membrane fusion (Belouzard et al., 2012).

\subsection{Role of spike protein}

The spike glycoprotein (S) plays a primary role in viral attachment and entry, cell tropism, and pathogenesis (Belouzard et al., 2012). The S protein contains two functional domains: the subunit (S1), an extracellular receptor-binding domain (RBD) responsible for virus binding, and the subunit (S2) anchored to the membrane which contains sequences responsible for membrane fusion (Holmes, 2003; Hofmann and Pöhlmann, 2004; Hoffmann et al., 2020). Membrane fusion requires spike (S) protein cleavage and activation by host cell proteases (Hoffmann et al., 2020).

The subunit S1 binds to the host cell receptor via two independent subdomains, an N-terminal domain (NTD) and C-terminal domain (CTD), capable of binding variety of proteins and sugars (Belouzard et al., 2012). The S2 subunit contains a fusion peptide with a transmembrane domain and a cytoplasmic domain which is highly conserved. While, spike receptor-binding domain (RBD) presents only $40 \%$ sequence identity with other SARS-CoVs.

RBD represents a binding site for the human angiotensin-converting enzyme 2 (ACE2) receptor and has a pivotal role in viral infection and pathogenesis (Abajo et al., 2020). ACE2 are metallopeptidase receptors present in every human organ, including lung (principally type II alveolar cells), heart, intestinal epithelium, kidney, vascular endothelium, and smooth muscle cells (Letko et al., 2020), ACE2 receptors are considered as an entry site for SARS-CoV and
SARS-CoV-2 into human respiratory epithelial cells (Cascella et al., 2020). Following the conjunction with the target receptor, the S1 subunit is bound to the peptidase domain of ACE2. Coronavirus fuses its envelope with the host cell membrane through the conformational change of S protein which is triggered by the target receptor binding, $\mathrm{pH}$ acidification, and proteolytic cleavage by endosomal proteases like transmembrane protease serine 2 (TMPRSS2) (Simmons et al., 2004; Millet and Whittaker, 2014).

The $\mathrm{S}$ protein is cleaved between $\mathrm{S} 1$ and $\mathrm{S} 2$ subunit and at the conserved site up stream of the fusion peptide (S2') (Figure 2) (Belouzard and Whittaker, 2009; Belouzard et al., 2012). After cleavage, the fusion between the two membranes is completed by the S2 portion (Suhail et al., 2020).

\begin{tabular}{|c|c|c|c|c|}
\hline S1 subunit & \multicolumn{4}{|c|}{ S2 subunit } \\
\hline RBD & & FP & HR1 & HR2 TM \\
\hline & $\underset{\mathrm{S} 1 / \mathrm{s} 2}{\uparrow}$ & $\begin{array}{l}\uparrow \\
S 2^{\prime}\end{array}$ & & \\
\hline
\end{tabular}

Figure 2: Schematic representation of the SARS-CoV spike protein (S).

The S1 subunit of $\mathrm{S}$ protein, containing RBD, responsible for specific recognition and binding of the target receptors. The S2 subunit, is in charge of the membrane fusion, contains the putative fusion peptide (FP) and the heptad repeat (HR1 and HR2), the transmembrane domain (TM). S1/S2 and S2' protease cleavage sites.

Depending on the specific coronavirus, RBD is used to recognize different functional receptors. The presence of an amino acid site (polybasic site) within the spike protein allows the functional processing by the human furin protease. This process allows the exposure of the fusion sequences and therefore the fusion of the viral and cell membranes, then the virus enters into the host cell (Cascella et al., 2020).

The importance of disulfide thiol balance in the viral entry of SARS-CoV-2 has been also demonstrated. Thiol and disulfide groups could act as electron donors and acceptors, respectively (Lavillette et al., 2006).

\subsection{Virus replication}

During virus infection, viral genetic material is fully released into the cytoplasm where takes place the replication and transcription process mediated by the replication/transcription complex (RTC) (Boopathi et al., 2020). The single stranded RNA is translated from open reading frame $1 \mathrm{a} / \mathrm{b}$ into ppla and pplab (viral replicase polyproteins), and then cleaved into nsps (Yesudhas et al., 2020). Viral replicase polyproteins use the genome as a template to generate full-length negative sense RNAs, themselves serving as templates to generate additional full-length genomes (Song et al., 2004). RNA polymerase produces upon transcription a series of subgenomic mRNAs translated into viral structural proteins S, E, N and M (Figure 3).

Viral proteins and RNA genome are assembled into new virions in Golgi and endoplasmic reticulum (ER). Indeed, the encapsidation of replicated genomes by $\mathrm{N}$ protein forms nucleocapsids in the cytoplasm, and they coalesce within the ERGIC (ER, Golgi 
intermediate compartment) membrane and then assembled into new virions. The newly formed virions are transported to the cell membrane in smooth walled vesicles and then outside secreted via exocytosis, so that can infect other cells (Figure 3).

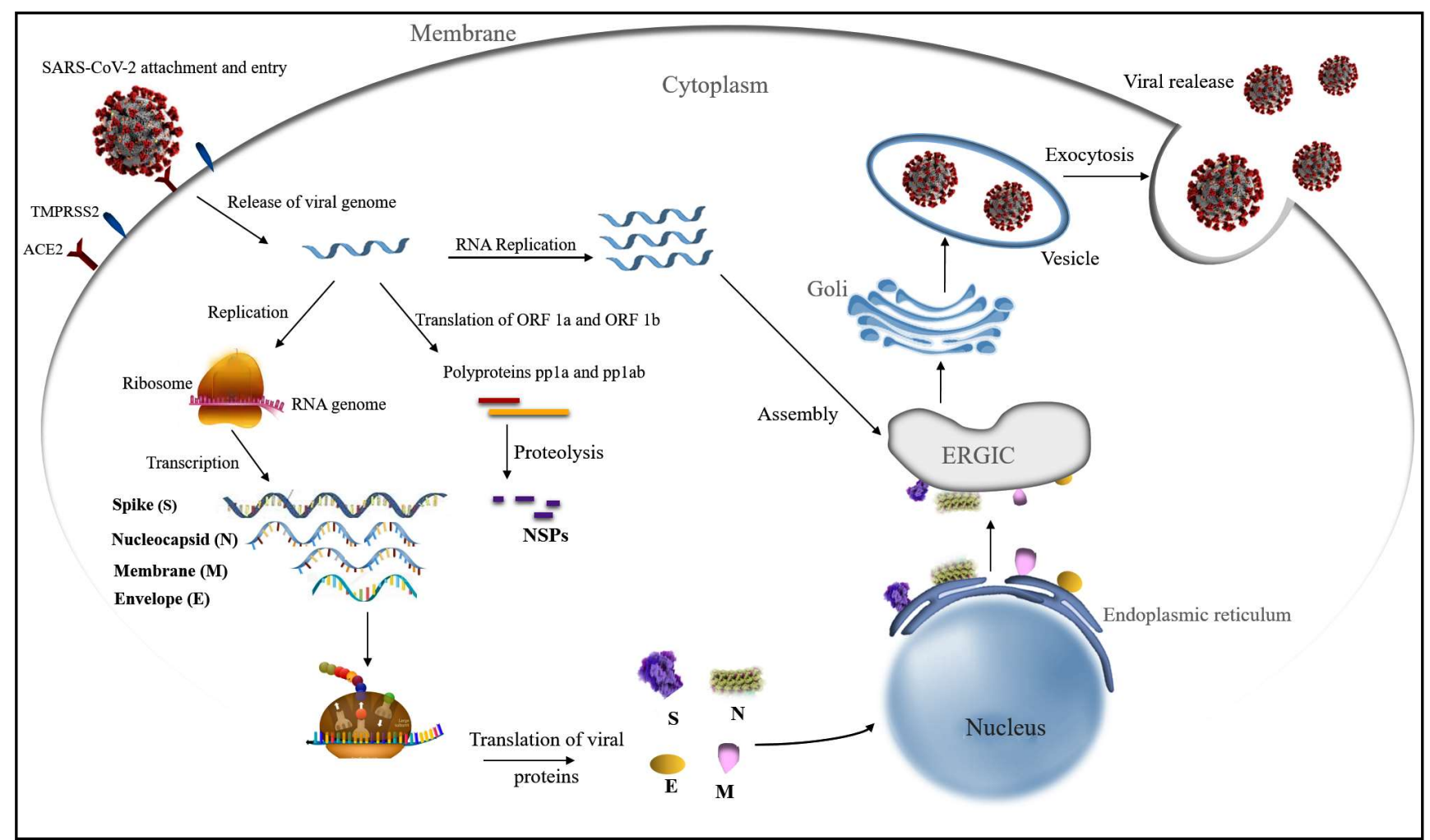

Figure 3: Schematic representation of SARS-CoV-2 attachment, internalization, and replication.

ACE2: angiotensin-converting enzyme 2, ERGIC: endoplasmique-reticulum-Golgi intermediate compartment, ORF: open reading frame, NSPs: non-structural protein. TMPRSS2: Transmembrane protease serine 2.

\subsection{Pathogenesis of SARS-CoV-2}

The mechanism of virulence of SARS-CoV-2 is mainly associated to the function of the nsps and structural proteins. Recent evidence showed that nsp is able to block the host innate immune response (Lei et al., 2018). Another mechanism is the severe inflammatory response induced by the viral infection in the lung as well as other organs (Lei et al., 2018). In fact, once the SARS-CoV-2 gains access inside the cells, it activates $\mathrm{T}$ lymphocytes and induces an intense immune response with subsequent release of cytokines which can cause real damage if they are not controlled (Song et al., 2018). As well, the SARS-CoV-2 utilizes its structural proteins to gain entry into the host cell cytosol as well as suppress signaling pathways particularly with the Toll-like receptors (TLR) (Weiss and NavasMartin, 2005).

\section{Inflammatory responses associated to COVID-19}

Accumulating evidence from epidemiological and clinical studies demonstrated that SARS-CoV-2 infection causes severe acute respiratory illness associated with massive inflammatory responses and cytokine storm secretion. Among these cytokines, tumor necrosis factor (TNF $\alpha$ ) and interleukin 1 (IL-1) are of considerable importance (Borthwick, 2016; Conti et al., 2020; Kritas et al., 2020).
The activation of toll like receptor (TLR) after SARS-CoV-2 binding induces a biochemical cascade that causes the secretion of pro-IL-1 cleaved by caspase- 1 into a mature fragment (IL-1), followed by the activation of the inflammasome (Chen et al., 2019; Conti et al., 2020; Tay et al., 2020). As well, SARS-CoV-2 entry, via, ACE2 activates pro-inflammatory cytokines including IL- 6 , TNF- $\alpha$, and inflammasome (Conti et al., 2020; Paniri and Akhavan-Niaki, 2020). Recently, increasing studies have reported that interleukin6 (IL-6) and NOD-like receptor protein 3 (NLRP3) inflammasome are the main cause of the inflammatory cytokine storm and pathological complications in infected patients with SARS-CoV-2 (Paniri and Akhavan-Niaki, 2020; Tay et al., 2020).

Previous in vitro cell experiments have shown delayed secretion of pro-inflammatory cytokine and chemokine (IL-6, TNF- $\alpha$, IL-1 $\beta$, IL-8, MCP-1, CCL2, CCL5, and IFNs) in respiratory epithelial cells, dendritic cells, and macrophages at the initial stage of SARS-CoV infection, then the release of cytokines and chemokines is enhanced by activated macrophages and other recruited lymphocytes (Cheung et al., 2005; Law et al., 2005; Lau et al., 2013).

Several other pro-inflammatory cytokines are produced following SARS-CoV-2 infection, notably CC chemokine ligand 2 (CCL2), C-X-C motif chemokine ligand 2 (CXCL2), CCL8, CXCL1, IL33, 
CCL3L1 in bronchoalveolar lavage fluid (BALF), and IP-10, tumor necrosis factor superfamily 10 (TNFSF), tissue inhibitors of metalloproteinases (TIMP)1, C5, IL18, amphiregulin, neuregulin1, and IL10 in peripheral blood mononuclear cells (PBMC), indicating sustained inflammation and cytokine storm in the patients. Pathway analysis of PBMC transcriptome revealed that lymphopenia in COVID-19 patients was more likely caused by the activation of apoptosis and P53 signaling pathway in lymphocytes (Xiong et al., 2020).

Zhou et al. (2020) demonstrated that BALF of patients with severe COVID-19 was enriched in CCL2 and CCL7, which are considered the most potent chemokines for the recruitment of CC-chemokine receptor 2-positive (CCR2+) monocytes. Likewise, Liao et al. (2020) found increased proportions of mononuclear phagocytes (MNPs) in BALF (up to $80 \%$ of total BALF cells in patients with severe COVID- 19 versus only $40 \%$ and $60 \%$ of total BALF cells in healthy or patients with moderate COVID-19, respectively).

Similarly, in severely affected patients, lymphopenia and interstitial pneumonia with elevated levels of pro-inflammatory cytokines, including IL-2, IL-6, IL-7, IL-1, G-CSF, IP-10, MCP-1, MIP-1 $\alpha$ and TNF $\alpha$ can be observed (Dong et al., 2020a ; di Mauro et al., 2020). However, Huang et al. (2020) detected elevated expression of IL-1 $\beta$, IFN- $\gamma$, IP-10 and monocyte chemo-attractive protein 1 (MCP-1) in patients with COVID-19. These inflammatory cytokines may activate the T-helper type 1 (Th1) cell response and play a key event in the activation of specific immunity (Huang et al., 2020; Marchingo et al., 2020). Moreover, these cytokines induce the recruitment and activation of neutrophils, NK cells, and adaptive immune $\mathrm{T}$ cells, with additional production of proinflammatory cytokines, causing consequently cytokine storm and tissue damage (Lingeswaran et al., 2020). While, Chen et al. (2020) recorded high levels of cytokines secreted by Th2 cells such as IL-4 and IL-10 in patients with COVID-19 responsible for inhibiting the inflammatory response.

SARS-CoV-2 induces a particular signature and differs from other coronaviruses in its capacity to replicate within pulmonary tissue. The virus can counteract the antiviral effects of IFN-I and IFN-III, activate innate responses with subsequent production of cytokines that regulate adaptive immunity (García, 2020).

A fatal inflammatory response and acute respiratory distress syndrome may be seen in patients with SARS-CoV-2 following rapid viral replication. This phenomenon can be explained by the cell lysis induced by over activation of the complement system following an interaction of the nucleocapsid dimers of the coronavirus released with the serine proteases associated to the lectin bound to mannose (Tok and Tatar, 2017; Shurin et al., 2020). Moreover, Dong et al. (2020b) suggest that the etiology of severe COVID-19 infection may be haemophagocytosis or macrophage activation syndrome.

\section{Oxidative stress and SARS-CoV infection}

During COVID-19 pandemic, very old patients and centenarians were more vulnerable to virus infection. Several in vitro and in vivo studies have demonstrated that age-related diseases are correlated with an elevated oxidative status (Schöttker et al., 2015; Schöttker et al., 2016 ; Gào et al., 2019). Emerging data and the clinical reports suggest that oxidative stress contributes to viral pathogenesis of SARS-CoV-2 (Cecchini and Cecchini, 2020; Delgado-Roche and Mesta, 2020). In fact, increases in ROS generation during aging lead to functional alterations, pathological conditions, and even death (Hagen, 2003; Kregel and Zhang, 2006).

Lin et al. (2006), reported that SARS-CoV 3C-like protease caused a significant increase in ROS production in HL-CZ promonocyte cells. The authors indicated that SARS-CoV-3C-like protease activates NF-kB-dependent reporter gene, which induced apoptosis of human promonocyte cells. Other studies have also reported that ROS mediated apoptosis in viral infections, such as Japanese encephalitis virus (Yang et al., 2010) and influenza virus (Uchide et al., 2002). Shao and coworkers (2006) identified that genes encoded in mitochondria, the main origin of intracellular free radicals production, and some genes responding to oxidative stress wes upregulated in peripheral blood mononuclear cells of convalescent SARS-CoV patients.

ACE2 receptor emerges as a key regulator in oxidative stressmediated SARS-CoV-2 infection. ACE2 is a membrane-bound protein responsible for the degradation of Ang II (Zheng et al., 2020). The latter enhances the production of ROS through enhancing NADPH oxidase activity, as a result, cysteine residues are oxidized to form disulfides, which in turn increase the affinity of SARS-CoV-2 $S$ proteins for the ACE2 receptor, and therefore, increase the severity of COVID-19 infection (Busse et al., 2020; Hati and Bhattacharyya, 2020).

SARS-CoV-2 infection causes acute lung injury and aggressive inflammatory response with excessive production of cytotoxic mediators such as ROS and RNS, tumor necrosis factor $\alpha$ (TNF $\alpha$ ), interleukins (IL-2, IL-6, IL-7), interferons (IFN- $\gamma$ ), granulocyte macrophage colony-stimulating factor (GM-CSF), monocyte chemotactic protein 3 ( MCP-3), interferon- $\gamma$-inducible protein 10 (IP-10) (Kaur et al., 2020) which are the source of oxidative stress associated with acute lung injury (Valavanidis et al., 2013).

During a SARS-CoV-2 infection, human erythrocytes are particularly prone to viral invasion and the pathophysiology of COVID-19 because of their high content of iron which is a critical redox catalyst for diverse viral processes including genome replication and protein synthesis (Abraham, 2020). Therefore, the lysis of erythrocytes leads to an increase of inflammatory cytokines, free heme, and free iron. A meta-analysis study of 1210 COVID-19 patients showed a dramatical decrease of hemoglobin levels of 7.1 $\mathrm{g} / 1$ or even $5.9 \mathrm{~g} / 1$ in severe cases (Lippi and Mattiuzzi, 2020). In fact, erythrocytes lysis increases the amount of extracellular $\mathrm{Hb}$ which in the highly oxidative environment leads to MetHb formation and the release of free heme (Dutra and Bozza, 2020). The prooxidant effects of free $\mathrm{Hb}$ are mainly attributed to heme release from oxidized $\mathrm{Hb}$. Free heme can react with lipids in cellular membranes, inducing lipid peroxidation, and increase cell permeability leading to hemolysis (Bellik and Iguer-Ouada, 2016). Moreover, free $\mathrm{Hb}$ can react with $\mathrm{NO}$ to generate peroxynitrite 
$\left(\mathrm{ONOO}^{-}\right)$which in turn generates reactive hydroxyl radical $(\mathrm{HO} \cdot)$ by the reaction with iron. $\mathrm{HO}^{*}$ can also cause membrane lipid peroxidation and cellular damage (Halliwell and Gutteridge, 1999; Authen and Davis, 2009). In addition, it has been demonstrated that iron induces blood coagulation via hydroxyl radicals which convert soluble plasma fibrinogen into abnormal fibrin clots in the form of dense matted deposits resistant to enzymatic degradation (Pretorius et al., 2013).

\section{Phytochemicals as potential agents against coronaviruses}

Plants have been the basis of traditional medicine and are a rich source of pharmacologically-active compounds used to develop new drugs. A wide range of bioactive components have been shown to modulate inflammatory responses. Table 1 summarizes the most studied and well-known phytochemicals with antiviral activity and their cellular and molecular mechanism. It is worth noting that several other reports demonstrating similar results are not represented here.

Table 1: Antiviral activity of selected phytochemicals against coronaviruses

\begin{tabular}{|c|c|c|c|c|c|}
\hline Plant & Bioactive compound & Virus type & Mechanism & Effect/dose & Reference \\
\hline $\begin{array}{l}\text { Green tea (Camellia } \\
\text { sinensis) }\end{array}$ & $\begin{array}{l}\text { Catechins (catechin; epigallo-, } \\
\text {-epi, - gallo, -catechin gallate; } \\
\text {-epigallo, -epi, -gallo catechin) }\end{array}$ & SARS-CoV-2 & $\begin{array}{l}\text { Inhibition of major protease } \\
\text { (H-bonds with amino acids of } \\
\text { catalytic site) }\end{array}$ & n.a. & $\begin{array}{l}\text { Ghosh et al. } \\
(2020)\end{array}$ \\
\hline $\begin{array}{l}\text { Brown algae } \\
(\text { Ecklonia cava) }\end{array}$ & $\begin{array}{l}\text { Phlorotannins }(8,8 \text { '-Bieckol, } \\
\text { 6,6'-Bieckol, Dieckol) }\end{array}$ & SARS-CoV-2 & 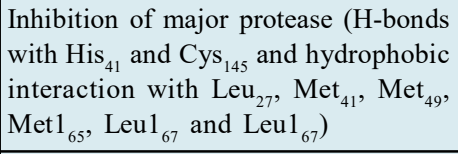 & n.a. & $\begin{array}{l}\text { Gentile et al. } \\
(2020)\end{array}$ \\
\hline $\begin{array}{l}\text { Marine sponge } \\
\text { (Theonella swinhoei) }\end{array}$ & Pseudotheonamide D and C & SARS-CoV-2 & $\begin{array}{l}\text { Inhibition of major protease } \\
(\text { Covalent bond with Cys } \\
\text { hydrophobic interaction with } \mathrm{Leu}_{27} \text {, } \\
\text { Met }_{49}, \mathrm{Phe}_{140} \text { and Leu }{ }_{67} \text { ) }\end{array}$ & n.a. & $\begin{array}{l}\text { Gentile et al. } \\
(2020)\end{array}$ \\
\hline $\begin{array}{l}\text { Paper birch (Betula } \\
\text { papyrifera) }\end{array}$ & Papyriflavonol A & SARS-CoV & $\begin{array}{l}\text { Inhibition of proteases ( } 3 \text {-chymotrypsin- } \\
\text { like protease and papain-like protease) }\end{array}$ & IC50: $3.7 \mu \mathrm{M}$ & $\begin{array}{l}\text { Park et al. } \\
(2017)\end{array}$ \\
\hline $\begin{array}{l}\text { Paulownia (Paulownia } \\
\text { tomentosa) }\end{array}$ & $\begin{array}{l}\text { Geranylated flavonoids } \\
\text { (tomentin A, B, C, D and E) }\end{array}$ & SARS-CoV & Inhibition of papain-like protease & $\begin{array}{l}\text { IC 50: } \\
5.0-14.4 \mu \mathrm{M}\end{array}$ & $\begin{array}{l}\text { Cho et al. } \\
(2013)\end{array}$ \\
\hline $\begin{array}{l}\text { Chinese rhubarb } \\
\text { (Rheum officinale) and } \\
\text { polygoni multiflori } \\
\text { (Polygonum } \\
\text { multiflorum) }\end{array}$ & $\begin{array}{l}\text { Emodin (6-methyl-1,3,8- } \\
\text { trihydroxyanthraquinone) }\end{array}$ & SARS-CoV & $\begin{array}{l}\text { Blocks the binding of spike protein } \\
\text { and angiotensin-converting enzyme } \\
2 \text { to host cells }\end{array}$ & 1 to $10 \mu \mathrm{g} / \mathrm{ml}$ & $\begin{array}{l}\text { Ho et al. } \\
(2007)\end{array}$ \\
\hline Flavonoids rich plants & $\begin{array}{l}\text { Herbacetin (flavonol), rhoifolin } \\
\text { and pectolinarin (flavones) }\end{array}$ & SARS-CoV & $\begin{array}{l}\text { Inhibition of } 3 \text {-chymotrypsin-like } \\
\text { protease (H-bonds with amino acids } \\
\text { of catalytic site) }\end{array}$ & $\begin{array}{l}\text { IC 50: } \\
27.5-37.8 \mu \mathrm{M}\end{array}$ & $\begin{array}{l}\text { Jo et al. } \\
(2020)\end{array}$ \\
\hline $\begin{array}{l}\text { Chinese mahogany } \\
\text { (Toona sinensis) }\end{array}$ & Quercetin & SARS-CoV & Inhibition of virus replication & IC50:500 $\mu \mathrm{g} / \mathrm{ml}$ & $\begin{array}{l}\text { Chen et al. } \\
(2008)\end{array}$ \\
\hline $\begin{array}{l}\text { Red spider lily } \\
\text { (Lycoris radiate) }\end{array}$ & Lycorine & SARS-CoV & Inhibition of cytopathic effect & EC50: $2.4 \mu \mathrm{g} / \mathrm{ml}$ & $\begin{array}{l}\text { Li et al. } \\
(2005)\end{array}$ \\
\hline $\begin{array}{l}\text { Brown algae } \\
(\text { Ecklonia cava) }\end{array}$ & Dieckol & SARS-CoV & $\begin{array}{l}\text { Inhibition of } 3 \text {-chymotrypsin-like } \\
\text { cysteine protease }(\mathrm{H} \text {-bond with } \\
\left.\text { catalytic dyad : } \mathrm{His}_{41} \text { and } \mathrm{Cys}_{145}\right)\end{array}$ & IC50: $2.7 \mu \mathrm{M}$ & $\begin{array}{l}\text { Park et al. } \\
(2013)\end{array}$ \\
\hline $\begin{array}{l}\text { Plants rich in } \\
\text { flavonoids }\end{array}$ & $\begin{array}{l}\text { Flavonoids: Herbacetin, } \\
\text { isobavachalcone, quercetin } 3 \beta \\
\text { d glucoside and helichrysetin }\end{array}$ & MERS CoV & $\begin{array}{l}\text { Inhibition of } 3 \text {-chymotrypsin-like } \\
\text { cysteine protease (H-bonds and } \\
\text { hydrophobic interactions) }\end{array}$ & $\begin{array}{l}\text { IC50: } 36-67 \mu \mathrm{M} \\
(20 \mu \mathrm{M})\end{array}$ & 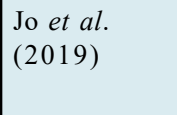 \\
\hline $\begin{array}{l}\text { Babchi } \\
\text { (Psoralea corylifolia) }\end{array}$ & $\begin{array}{l}\text { Flavonoids: Bavachinin, } \\
\text { neobavaisoflavone, } \\
\text { isobavachalcone, 4'-O- } \\
\text { methylbavachalcone, } \\
\text { psoralidin and corylifol A. }\end{array}$ & SARS-CoV & Inhibition of papain-like protease & $\begin{array}{l}\text { IC50: } 4.2 \text { and } \\
38.4 \mu \mathrm{M}\end{array}$ & $\begin{array}{l}\text { Kim et al. } \\
(2014)\end{array}$ \\
\hline $\begin{array}{l}\text { Ashitaba } \\
\text { (Angelica keiskei) }\end{array}$ & Xanthoangelol E & SARS-CoV & $\begin{array}{l}\text { Inhibition of } 3 \text {-chymotrypsin-like } \\
\text { protease (H-bonds with His }{ }_{163}, \text { Ser }_{144} \\
\text { and Cys }{ }_{145} \text { )Inhibition of papain-like } \\
\text { protease (H-bonds with His }_{176} \text { and } \\
\text { His }_{172} \text { ) }\end{array}$ & $\begin{array}{l}\text { IC50: } 11.4 \mu \mathrm{M} \\
\text { IC50: } 1.2 \mu \mathrm{M}\end{array}$ & $\begin{array}{l}\text { Park et al. } \\
(2016)\end{array}$ \\
\hline
\end{tabular}




\begin{tabular}{|c|c|c|c|c|c|}
\hline Plant & Bioactive compound & Virus type & Mechanism & Effect/dose & Reference \\
\hline $\begin{array}{l}\text { Woad } \\
\text { (Isatis indigotica) }\end{array}$ & $\begin{array}{l}\text { Indigo } \\
\text { Sinigrin } \\
\text { Beta-sitosterol } \\
\text { Aloeemodin } \\
\text { Hesperetin } \\
\text { Daidzein }\end{array}$ & SARS-CoV & $\begin{array}{l}\text { Inhibition of 3-chymotrypsin-like } \\
\text { protease }\end{array}$ & $\begin{array}{l}\text { IC50: } 37.3 \mu \mathrm{M} \\
(300 \mu \mathrm{M}) \\
\text { IC50: } 50.3 \mu \mathrm{M} \\
(121 \mu \mathrm{M}) \\
\text { IC50: } 47.8 \mu \mathrm{M} \\
(115 \mu \mathrm{M}) \\
\text { IC50: } 35.7 \mu \mathrm{M} \\
(132 \mu \mathrm{M}) \\
\text { IC50: } 18.1 \mu \mathrm{M} \\
(60 \mu \mathrm{M}) \\
\text { IC50: } 6.8 \mu \mathrm{M} \\
(105 \mu \mathrm{M})\end{array}$ & $\begin{array}{l}\text { Lin et al. } \\
(2005)\end{array}$ \\
\hline $\begin{array}{l}\text { Plants rich in } \\
\text { anthocyanins } \\
\end{array}$ & Quercetin-3- $\beta$-galactoside & SARS-CoV & $\begin{array}{l}\text { Inhibition of 3-chymotrypsin-like } \\
\text { protease (H-bonds with } \mathrm{Gln}_{189} \text { ) }\end{array}$ & $42.8 \mu \mathrm{M}$ & $\begin{array}{l}\text { Chen et al. } \\
(2006)\end{array}$ \\
\hline $\begin{array}{l}\text { Coniferous tree } \\
\text { (Torreya nucifera) }\end{array}$ & Amentoflavone & SARS-CoV & $\begin{array}{l}\text { Inhibition of 3-chymotrypsin-like } \\
\text { protease (Interaction with } \mathrm{His}_{163} \text {, } \\
\text { Leu }_{141}, \mathrm{Gln}_{189 \& 192} \text { and } \mathrm{Val}_{186} \text { ) }\end{array}$ & $\begin{array}{l}\text { IC50: } 8.3 \mu \mathrm{M} \\
(14 \mu \mathrm{M})\end{array}$ & $\begin{array}{l}\text { Ryu et al. } \\
(2010 \mathrm{a})\end{array}$ \\
\hline $\begin{array}{l}\text { Plants rich in } \\
\text { flavonoids }\end{array}$ & $\begin{array}{l}\text { Quercetin, epigallocatechin } \\
\text { gallate and gallocatechin } \\
\text { gallate }\end{array}$ & SARS-CoV & 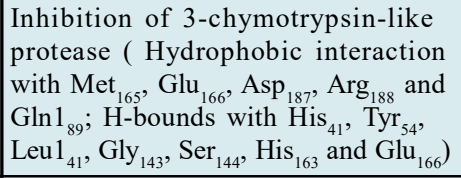 & $\begin{array}{l}\text { IC50: } 73,73 \\
\text { and } 47 \mu \mathrm{M}\end{array}$ & $\begin{array}{l}\text { Nguyen et al. } \\
(2012)\end{array}$ \\
\hline $\begin{array}{l}\text { Baikal skullcap } \\
\text { (Scutellaria } \\
\text { baicalensis) } \\
\end{array}$ & Scutellarein & SARS-CoV & $\begin{array}{l}\text { Inhibition of NTPase/helicase } \\
\left(\text { Interaction with } \mathrm{Asn}_{265}, \mathrm{Tyr}_{269} \text { and }\right. \\
\mathrm{Arg}_{443} \text { ) }\end{array}$ & IC50: $0.86 \mu \mathrm{M}$ & $\begin{array}{l}\text { Yu et al. } \\
(2012)\end{array}$ \\
\hline $\begin{array}{l}\text { Tea (Camellia } \\
\text { sinensis) }\end{array}$ & $\begin{array}{l}\text { (-)-Catechin gallate and (-)- } \\
\text { Gallocatechin gallate }\end{array}$ & SARS-CoV & $\begin{array}{l}\text { Inhibition of nucleocapsid protein } \\
\text { activity }\end{array}$ & $50 \mu \mathrm{M}$ & $\begin{array}{l}\text { Roh et al. } \\
(2012)\end{array}$ \\
\hline $\begin{array}{l}\text { Bitter orange (Citrus } \\
\text { aurantium) }\end{array}$ & Hesperidin & SARS-CoV-2 & $\begin{array}{l}\text { Inhibition of 3-chymotrypsin-like } \\
\text { protease and blocks the binding of } \\
\text { angiotensin-converting enzyme } 2 \\
\text { to Spike-receptor binding domain }\end{array}$ & n.a. & $\begin{array}{l}\text { Wu et al. } \\
(2020)\end{array}$ \\
\hline Citrus fruits & Naringenin & SARS-CoV-2 & $\begin{array}{l}\text { Inhibition 3-chymotrypsin-like } \\
\text { protease and reduction of angiotensin } \\
\text { converting enzyme activity }\end{array}$ & n.a. & $\begin{array}{l}\text { Tutunchi et al } \\
(2020)\end{array}$ \\
\hline $\begin{array}{l}\text { Plants riche in } \\
\text { phenolic compounds }\end{array}$ & $\begin{array}{l}\text { Theaflavins, hesperidin, } \\
\text { quercetagetin and myricetin }\end{array}$ & SARS-CoV-2 & $\begin{array}{l}\text { Inhibition of RNA replication } \\
\text { (Binding to RNA-dependent RNA } \\
\text { polymerase) }\end{array}$ & n.a. & $\begin{array}{l}\text { Singh et al. } \\
(2020)\end{array}$ \\
\hline $\begin{array}{l}\text { Bupleurum spp., } \\
\text { Heteromorpha spp. } \\
\text { and Scrophularia } \\
\text { scorodonia }\end{array}$ & Saikosaponin B2 & SARS-CoV & $\begin{array}{l}\text { Prevent viral adsorption and } \\
\text { penetration into cell hosts }\end{array}$ & IC50: $1.7 \mu \mathrm{M}$ & $\begin{array}{l}\text { Cheng et al. } \\
(2006)\end{array}$ \\
\hline $\begin{array}{l}\text { Prunella vulgaris and } \\
\text { Saussurea lappa }\end{array}$ & $\begin{array}{l}\text { Tetra-O-galloyl- } \beta \text {-d-glucose } \\
\text { and luteolin }\end{array}$ & SARS-CoV & $\begin{array}{l}\text { Prevent viral penetration into cell } \\
\text { hosts }\end{array}$ & $\begin{array}{l}\text { EC50: } 4.5 \text { and } \\
10.6 \mu \mathrm{M}\end{array}$ & $\begin{array}{l}\text { Yi et al. } \\
(2004)\end{array}$ \\
\hline $\begin{array}{l}\text { Alder } \\
\text { (Alnus japonica) }\end{array}$ & $\begin{array}{l}\text { Hirsutenone, rubranoside and } \\
\text { curcumin }\end{array}$ & SARS-CoV & $\begin{array}{l}\text { Inhibition of 3-chymotrypsin-like } \\
\text { protease }\end{array}$ & $\begin{array}{l}\text { IC50: } 4.1,7.2 \\
\text { and } 5.7 \mu \mathrm{M}\end{array}$ & $\begin{array}{l}\text { Park et al. } \\
(2012 \mathrm{a})\end{array}$ \\
\hline $\begin{array}{l}\text { Burra gokharu } \\
\text { (Tribulus terrestris) }\end{array}$ & $\begin{array}{l}\text { Terrestrimine, terrestriamide, } \\
\text { N-trans-feruloyloctopamine }\end{array}$ & SARS-CoV & $\begin{array}{l}\text { Inhibition of 3-chymotrypsin-like } \\
\text { protease }\end{array}$ & $\begin{array}{l}\text { IC50: } 15.8,21.5 \\
\text { and } 26.6 \mu \mathrm{M}\end{array}$ & $\begin{array}{l}\text { Song et al. } \\
(2014)\end{array}$ \\
\hline Calophyllum blancoi & $\begin{array}{l}\text { Blancoxanthone and } \\
\text { pyranojacaeubin }\end{array}$ & $\mathrm{HCoV} 229 \mathrm{E}$ & 1 & $\begin{array}{l}\text { EC } 50 \%: 3 \text { and } \\
15 \mathrm{mg} / \mathrm{ml}\end{array}$ & \begin{tabular}{|l} 
Shen et al. \\
$(2005)$
\end{tabular} \\
\hline $\begin{array}{l}\text { Regel's threewingnut } \\
\text { (Tripterygium regelii) }\end{array}$ & $\begin{array}{l}\text { Iguesterin, pristimerin, } \\
\text { tingenone and celastrol }\end{array}$ & SARS-CoV & 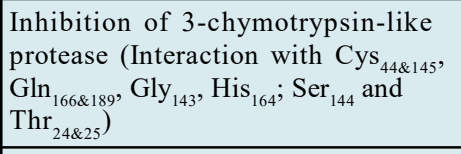 & $\begin{array}{l}\text { IC50: 2.6, 5.5, } \\
9.9 \text { and } 10.3 \mu \mathrm{M}\end{array}$ & $\begin{array}{l}\text { Ryu et al. } \\
(2010 \mathrm{~b})\end{array}$ \\
\hline $\begin{array}{l}\text { Assam indigo } \\
\text { (Strobilanthes cusia) }\end{array}$ & Tryptanthrin & SARS-CoV & $\begin{array}{l}\text { Inhibition of 3-chymotrypsin-like } \\
\text { protease (Interaction with } \mathrm{Ile}_{106} \text {, } \\
\left.\text { Val }_{104} \text { and } \mathrm{Gln}_{110}\right)\end{array}$ & IC50: $1.25 \mu \mathrm{M}$ & $\begin{array}{l}\text { Narkhede } \\
\text { et al. }(2020)\end{array}$ \\
\hline $\begin{array}{l}\text { Red sage } \\
\text { (Salvia miltiorrhiza) }\end{array}$ & $\begin{array}{l}\text { Tanshinone I and } \\
\text { dihydrotanshinone I }\end{array}$ & SARS-CoV & $\begin{array}{l}\text { Inhibition of 3-chymotrypsin-like } \\
\text { protease }\end{array}$ & $\begin{array}{l}\text { IC50: } 0.7 \text { and } \\
1.2 \mu \mathrm{M}\end{array}$ & $\begin{array}{l}\text { Park et al. } \\
(2012 \mathrm{~b})\end{array}$ \\
\hline
\end{tabular}




\section{Roles of essential oils}

Essential oils (EOs) are valuable natural products that have been used over the years in aromatherapy and phytomedicine due to their antiviral, antibacterial, antifungal, antioxidant, immunomodulatory and anti-inflammatory effects (Asif et al., 2020; Astani and Schnitzler, 2014; Gilling et al., 2014).

Most research studies on the antiviral activity of the essential oils have been conducted towards enveloped viruses. Still, little works were performed on non-enveloped viruses (Gilling et al., 2014).

EOs could act by destabilizing virions, protecting host cell or inhibiting replication once the virus invades the host cell (Astani and Schnitzler, 2014). Five mechanisms of action induced-antiviral activity of essential oils have been described: direct actions on free viruses, inhibition of steps involved in virus attachment, penetration, intracellular replication, and release from host cells, and inhibition of vital enzymes (Schnitzler et al., 2010; Asif et al., 2020; Ma and Yao, 2020).

\subsection{Direct actions on free viruses}

Several studies have shown the ability of many EOs to disrupt biological membranes as well as viral envelopes (Siddiqui et al., 1996; Nguefack et al., 2004; Xu et al., 2008). Due to their lipophilic nature (Wink, 2020), EOs are able to insert nonspecifically into the viral envelope lipid bilayer which can result in the alteration of normal membrane fluidity (Ben-Shabat et al., 2020; Wink, 2020). Membranes can also be ruptured if the EOs are present at higher concentrations (Wink, 2020). Siddiqui et al. (1996) demonstrated that oregano oil (Origanum vulgare) and clove oil (Syzygium aromaticum) destroyed human pathogen herpes simplex virus type 1 (HSV-1) envelope. Likewise, Brochot et al. (2017) reported that 1,8-cineole, derived from eucalyptus oil, damaged the envelope structures of the free Influenza A virus and could inactivate this virus. Reichling et al. (2006) found that monoterpenes increased the fluidity and permeability of the cytoplasmic membrane and disrupted the order of membrane proteins.

Moreover, the antiviral activity of EOs may be the result of a disruption or interference with the viral membrane proteins involved in the attachment of host cells (Schuhmacher et al., 2003). Mediouni et al. (2020) showed that carvacrol obtained from oregano was effective at blocking the entry of HIV-1 virus into the host system by inhibiting the fusion of host viral cells via depletion of viral cholesterol from HIV-1 envelope membrane.

\subsection{Inhibition of virus attachment and penetration}

In vitro and in vivo results showed that the total amount of pulmonary nuclear factor-erythroid 2-related factor $2(\mathrm{Nrf} 2)$ and the nuclear translocation of Nrf2 was high in treated rats with diallyl sulfide (DAS), the main sulfur component of Garlic essential oils (Ho et al., 2012; Dziri et al., 2014). McCord et al. (2020) observed that potent activation of Nrf2 causes a decrease in the expression of ACE2 and TMPRSS2 mRNA in HepG2 cells of human hepatic origin. Based on these findings, it has been proposed that Garlic essential oils and their isolated constituents, especially DAS, have the potential to prevent entry of viruses into host cells (Asif et al., 2020). Similarly, the results obtained by
Thuy et al. (2020) using molecular docking technique showed that 17 organosulfur compounds, representing $99.4 \%$ of the Garlic essential oil, have strong interactions with the amino acids of the ACE2 protein and the main protease PDB6LU7 of SARS-CoV-2. Senthil Kumar et al. (2020) examined the ACE2 inhibitory effects of major constituents of Geranium and Lemon essential oils, namely; citronellol $(50 \mu \mathrm{M})$, geraniol $(50 \mu \mathrm{M})$, limonene $(50 \mu \mathrm{M})$, and neryl acetate $(50 \mu \mathrm{M})$. The results showed that these compounds reduced the ACE2 levels from $18.0 \mathrm{ng} / \mathrm{ml}$ (control) to $7.67 \mathrm{ng} / \mathrm{ml}, 10.44 \mathrm{ng} / \mathrm{ml}, 12.92 \mathrm{ng} / \mathrm{ml}$, and $16.63 \mathrm{ng} / \mathrm{ml}$, respectively.

In silico study showed that isothymol, thymol, limonene, $p$-cymene, and $\gamma$-terpinene from Ammoides verticillata essential oil could have inhibitory effect on ACE2. The study revealed also that isothymol, a major component of the plant, could be a very effective inhibitor of the enzyme ACE2 (Abdelli et al., 2020). Another in silico study reported that thymoquinone, the main compound of Nigella sativa essential oil, would be the best candidate drug that may inhibit protease SARS-CoV-2 and ACE2 (Sekiou et al., 2020).

\subsection{Inhibition of intracellular replication}

Recent studies performed by the use of molecular docking to investigate the effects of two components of Eucalyptus essential oil (jensenone and 1,8-cineole) on viral proteinase (Mpro/3CLpro) showed that 1,8-cineole can bind with Mpro via hydrophobic interactions, hydrogen bonding interactions, and strong ionic interactions and thus inhibit viral reproduction (Sharma and Kaur, 2020a; Sharma and Kaur, 2020b).

Kulkarni and coworkers (2020) carried out in silico study and found that anethole, cinnamaldehyde, carvacrol, geraniol, cinnamyl acetate, L-4-terpineol, thymol, and pulegone from essential oils inhibit the S1 subunit of S protein and that cinnamaldehyde had more favorable interaction points at the binding site than other compounds. Silva et al. (2020) studied 171 essential oil components against protease SARS-CoV-2 (SARS-CoV-2 Mpro), endoribonucleoase SARS-CoV-2 (SARS-CoV-2 nsp15/NendoU), SARS-CoV-2 ADP-ribose-1"-phosphatase (SARS-CoV-2 ADRP), RNA-dependent RNA polymerase of SARS-CoV-2 (SARS-CoV-2 $\mathrm{RdRp}$ ), the spike protein binding domain SARS-CoV-2 (SARS-CoV-2 rS) and human angiotensin converting enzyme (hACE2). It was found that the best docking ligands for the SARS-CoV target proteins were $(E, E)$ - $\alpha$-farnesene, $(E)$ - $\beta$-farnesene, and $(E, E)$ farnesol.

\subsection{Other effects of essential oil}

There are several reports showing the ability of essential oils to modulate immune system. The protective effects of cinnamaldehyde and eugenol in lipopolysaccharide (LPS)induced acute lung injury has been reported (Huang and Wang, 2017; Barboza et al., 2018). Cinnamaldehyde treatment inhibits neutrophils, macrophages, and total cell number in the bronchoalveolar lavage fluid and decreased the levels of inflammatory cytokines such as TNF- $\alpha$, IL-6, IL-13 and IL-1 $\beta$, respectively (Huang and Wang, 2017). Similarly, the levels of interleukin-1, interleukin-23, and tumor necrosis factor $\alpha$ (TNF$\alpha$ ) decreased considerably in treated rats with menthol (Rozza et al., 2014; Bastaki et al., 2018). Eugenol was also found to 
inhibit the recruitment of leukocytes into the lung and downregulated the expression of pro-inflammatory cytokines (IL-6 and TNF- $\alpha$ ) (Barboza et al., 2018). Furthermore, monoterpenes thymol, carvacrol and p-cymene reduced the positive cells to NF- $\kappa \mathrm{B}$ in lung which consequently reduced inflammatory response (Edwards et al., 2009). In addition, Games et al. (2016) demonstrated that the treatment with thymol, carvacrol and p-cymene isolated from essential oil of Lippia sidoides Cham. (Verbenaceae) leaves reduced alveolar enlargement, macrophage recruitment, cytokine levels (IL-1 $\beta$, IL6 , IL-8, and IL-17) in bronchoalveolar lavage fluid, and collagen fibers, MMP-9 as well as p-65-NF- $\mathrm{kB}-$ positive cells in lung parenchyma.

In vitro and ex vivo studies have demonstrated marked immunomodulatory properties of both Eucalyptus essential oil and its active ingredient, namely eucalyptol. Treatment with Eucalyptus essential oil and its main compound eucalyptol reduced the release of pro-inflammatory cytokines by monocytes and macrophages, without affecting their phagocytic properties (Sadlon and Lamson, 2010; Juergens et al., 2020).

\section{Roles of oligoelements and vitamins}

Many vitamins and oligoelements are essential for the proper functioning of the immune system (Wintergerst et al., 2007), because of their anti-inflammatory, antioxidant, and antiviral properties (Beard et al., 2011). The efficiency of innate and adaptive immune responses depends on the level of these elements. Below are described some of the most studied vitamins and trace elements that have shown promising effects against COVID-19.

\subsection{Vitamin $C$}

Vitamin $\mathrm{C}$ is one of the most used therapeutic agents in the treatment of human diseases. It is considered as an antioxidant and an enzymatic cofactor for many physiological reactions in the body, such as hormone production, collagen synthesis, and immune potentiation (Kim et al., 2013). It has been proposed as a promising therapeutic approach for reducing the susceptibility of people at high risk to lower respiratory infection under certain conditions (Hemilä, 1997). Vitamin C is essential for innate and adaptive immunity. In vitro study showed that vitamin $\mathrm{C}$ supplementation improved the proliferation and activation of lymphocytes in dose dependent manner (Huijskens et al., 2014). Liugan and Carr (2019) reported that neutrophil's chemotaxis, phagocytosis, and oxidative burst activity are enhanced in the presence of vitamin C. It also displayed specific epigenetic characteristics on immune cells such as dendritic cells, monocytes/ macrophages, T cells, NK cells (Ang et al., 2018). Treatment with vitamin $C$ reduced pro-inflammatory cytokines TNF, IL-6, and $\mathrm{IL}-1 \beta$. Administration of $1 \mathrm{~g}$ /day vitamin $\mathrm{C}$ was shown to enhance PBMC, IL-10, IL-1, and TNF- $\alpha$ following stimulation with LPS (Jeng et al., 1996; Canali et al., 2014).

Interestingly, it has been demonstrated that intravenous administration of vitamin $\mathrm{C}$ high-dose reduces cytokine storm in acute respiratory distress syndrome, improves immune system function, and increases antiviral properties during SARS-CoV-2 infection (Boretti and Banik, 2020). Similarly, Cheng (2020) pointed out that intravenous administration of early and adequate dose of vitamin $\mathrm{C}$ can be used to reduce the mortality and morbidity due to COVID-19.

\subsection{Vitamin E}

Vitamin $\mathrm{E}$ is a potent fat-soluble antioxidant capable of modulating host immune functions (Moriguchi and Muraga, 2000). Vitamin E is essential for the humoral and innate immune systems. In fact, the scavenger properties of vitamin E gives them the ability to reduce oxidative stress, protect polyunsaturated fatty acids (PUFA) and immune cells against oxidation and also to exert antiinflammatory effects. But there are very few reports regarding the use and/or dosage of vitamin $\mathrm{E}$ as a prophylactic or therapeutic agent against COVID-19 (Fernández-Quintela et al., 2020). Combination of vitamin $E$ with vitamin $C$ should be considered in clinical trials. de la Fuente et al. (2008) found that supplementation of the diet of elderly men and women with $200 \mathrm{mg} /$ day vitamin $\mathrm{E}$, in combination with vitamin $\mathrm{C}$, enhanced phagocytic functions of polymorphonuclear.

\subsection{Vitamin D}

Vitamin D, a fat soluble vitamin, plays an important role in modulating both innate and adaptive immune responses (Aranow, 2011). Previous studies have shown that vitamin D increased chemotaxis, autophagy, and phagolysosomal fusion of innate immune cells (Liu et al., 2007; White et al., 2010). Vitamin D can also enhance the antimicrobial activity of macrophage and monocyte keratinocytes.

Vitamin D exerts its anti-inflammatory effects by suppressing the production of pro-inflammatory cytokines such as IFN- $\gamma$, IL-6, IL2, and TNF- $\alpha$ (Xie et al., 2015; Carvalho et al., 2017). It is strongly involved in respiratory homeostasis by stimulating the expression of antimicrobial peptides and by interfering with replication of respiratory viruses (Zdrenghea et al., 2017). Moreover, vitamin D preserves tight junctions, disrupts enveloped viruses by inducing cathelicidin and defensins, and prevents the cytokine storm that leads to pneumonia (Muscogiuri et al., 2020). Recently, randomized controlled trials showed that high-dose vitamin D supplementation improved the health status of mechanically ventilated critically ill patients (enhancing the capacity of blood for oxygen transport and increasing hemoglobin levels) (Han et al., 2016; Smith et al., 2018).

Among the consequences of SARS-CoV-2 infection, the decreased levels of circulating vitamin D. Vitamin D receptors are highly expressed by several immune cells in particular monocytes, $\mathrm{T}$ and B lymphocytes. Therefore, vitamin D deficiency is associated with increased risk of respiratory viral infection (Fernandes et al., 2020). Ilie and collaborators (2020) have studied the role of vitamin D in the prevention of COVID-19 infection and mortality among 20 European countries. They found a negative correlation between the level of vitamin D and the number of COVID-19 cases, as well as COVID-19 mortality.

\subsection{Zinc}

Zinc is an important trace element which plays a pivotal role in growth, development, and the maintenance of the immune system (Prasad, 2013; Read et al., 2019). It increases activity of macrophages, production of immunoglobulins and cytolysis of natural killer (Shankar and Prasad, 1998). 
$\mathrm{Zn}$ has a direct action on viruses, such as influenza and coronavirus, maybe through inhibition of RNA-dependent RNA polymerase or by inhibiting the formation of the viral coating and processing of its structural components (Read et al., 2019). Zn interacts with interferon-lambda3 binding to IFNL receptor 1 on HCV and influenza (Read et al., 2017). Zhang and Liu (2020) confirmed that the combination of zinc and pyrithione at low concentrations contributes to the reduction of SARS-CoV replication.

Administration of $75 \mathrm{mg}$ of zinc per day has been shown to alleviate symptoms of illness in patients with viral infections (Singh and Das, 2013). It has been suggested that zinc intakes of 30-50 mg per day might aid control of RNA viruses including influenza and coronavirus (McCarty and DiNicolantonio, 2020). Xue et al. (2014) demonstrated a synergistic effect of chloroquine with zinc in terms of cytotoxic effect on human cancer cells, this reinforces the fact of combining between the antimalarial and zinc for other conditions such as viral infections.

\subsection{Selenium}

Selenium is an essential oligoelement, which plays an important role in multiple metabolic reactions in the organism (Prabhu and Lei, 2016). It is a cofactor of many enzymes such as glutathione peroxidase or thioredoxin reductase and exerts its functions linked with protein forming selenoprotein (Duntas and Benvenga, 2015). It has antioxidant and immune properties. Adequate levels of selenium can reduce inflammation by decreased expression of pro-inflammatory mediators such as cytokines, the redox-sensitive transcription factor NF-kappa B, increase the production of interferon-gamma (Gombart et al., 2020).

Zhang et al. (2020) showed that infected patients with increased selenium levels were more prone to recover from COVID-19. This has been also reported previously on other viral infections such as HIV (Taylor et al., 2016), hepatitis B-mediated liver cancer (Steinbrenner et al., 2015), or epidemic hemorrhagic fever (Hou, 1997).

\section{Future perspectives}

The recent emergence of the novel coronavirus along with the rapid and continuous evolution of the pandemic has caused serious threats to public health and greatest economic, social, and medical losses worldwide. Nowadays, there is an increasing gravity of the situation, a lack of appropriate detection assays for the identification of SARS-CoV-2 infected patients, and an incapacity of the existent therapeutic interventions to manage COVID-19. Therefore, there is a global emergency that needs new approaches to eradicating this global crisis. Evidence from this work supports the fact that plant phytochemicals could be a successful target-specific drug against viral infections. At the moment, scientists and clinicians are dedicating all the efforts to ameliorate prevention, treatment, and control of COVID-19. It is well understood that an effective or ideal vaccine will take more time to fully develop, so nations and officials will need massive efforts to minimize the impact of future epidemics.

\section{Conflict of interest}

The authors declare that there are no conflicts of interest relevant to this article.

\section{References}

Abajo, F.J.; Rodríguez-Martín, S.; Lerma, V.; Mejía-Abril, G.; Aguilar, M.; GarcíaLuque, A.; Laredo, L.; Laosa, O.; Centeno-soto, G.A.; Galvez, M.A.; Puerro, M.; Gonzalez-Rojano, E.; Pedraza, L.; Pablo, I.; Abad-Santos, F.; RodriguezManas, L.; Gil, M.; Tobias, A.; Rodriguez-Miguel A. and Rodriguez-Puyol, D. (2020). Use of renin-angiotensin-aldosterone system inhibitors and risk of COVID-19 requiring admission to hospital: A casepopulation study. The Lancet, 30;395(10238):1705-1714. doi: $10.1016 / \mathrm{S} 0140-6736(20) 31030-8$.

Abdelli, I.; Hassani, F.; Bekkel Brikci, S. and Ghalem, S. (2020). In silico study the inhibition of angiotensin converting enzyme 2 receptor of COVID-19 by Ammoides verticillata components harvested from Western Algeria. J. Biomol. Struct. Dyn., pp:1-14. https://doi.org/ $10.1080 / 07391102.2020 .1763199$

Abraham, L. (2020). Covid-19: Acquired acute porphyria hypothesis. OSF Preprints. https://doi.org/10.31219/osf.io/4wkfy

Ang, A.; Pullar, J.M.; Currie, M.J. and Vissers, M.C.M. (2018). Vitamin C and immune cell function in inflammation and cancer. Biochem. Soc. Trans., 46(5):1147-1159. https://doi.org/10.1042/BST20180169

Aranow, C. (2011). Vitamin D and the immune system. J. Invest. Med., 59(6):881-886. https://doi.org/10.1042/BST20180169

Asif, M.; Saleem, M.; Saadullah, M.; Yaseen, H. S. and AI Zarzour, R. (2020). COVID-19 and therapy with essential oils having antiviral, anti-inflammatory, and immunomodulatory properties. Inflammopharmacology, 28(5):1153-1161. https://doi.org/10.1007/s10787-020-00744-0

Astani, A. and Schnitzler, P. (2014). Antiviral activity of monoterpenes beta-pinene and limonene against herpes simplex virus in vitro. Iran. J. Microbiol., 6(3):149-155.

Authen, R.L. and Davis, J.M. (2009). Oxygen toxicity and reactive oxygen species: The devil is in the details. Pediatr. Res., 66:121-127. doi: 10.1203/PDR.0b013e3181a9eafb.

Barboza, J.N.; da Silva Maia Bezerra Filho, C.; Silva, R.O.; Medeiros, J. and de Sousa, D.P. (2018). An overview on the anti-inflammatory potential and antioxidant profile of eugenol. Oxid. Med. Cell. Longev., 2018:3957262. https://doi.org/10.1155/2018/3957262

Bastaki, S.M.; Adeghate, E.; Amir, N.; Ojha, S. and Oz, M. (2018). Menthol inhibits oxidative stress and inflammation in acetic acid-induced colitis in rat colonic mucosa. Am. J. Transl. Res., 10:4210-4222.

Beard, J.A.; Bearden, A. and Striker, R. (2011). Vitamin D and the anti-viral state. J. Clin. Virol., 50:194-200. https://doi.org/10.1016/ j.jcv.2010.12.006

Bellik, Y. and Iguer-Ouada, M. (2016). Concurrent measurement of cellular turbidity and hemoglobin to evaluate the antioxidant activity of plants. Food. Chem., 190:468-473. https://doi.org/10.1016/ j.foodchem.2015.05.126

Belouzard, S.; Chu, V.C. and Whittaker, G.R. (2009). Activation of the SARS coronavirus spike protein via sequential proteolytic cleavage at two distinct sites. Proc. Natl. Acad. Sci. USA., 106:5871-5876. https://doi.org/10.1073/pnas.0809524106

Belouzard, S.; Millet, J.K.; Licitra, B.N. and Whittaker, G.R. (2012). Mechanisms of coronavirus cell entry mediated by the viral spike protein. Viruses, 4:1011-1033. doi :10.3390/v4061011

Ben-Shabat, S.; Yarmolinsky, L.; Porat, D. and Dahan, A. (2020). Antiviral effect of phytochemicals from medicinal plants: Applications and drug delivery strategies. Drug. Deliv. Transl. Res., 10:354-367. doi: $10.1007 / \mathrm{s} 13346-019-00691-6$ 
Boopathi, S.; Poma, A.B. and Kolandaivel, P. (2020). Novel 2019 coronavirus structure, mechanism of action, antiviral drug promises and rule out against its treatment. J. of Biomolecular Structure and Dynamics, pp:1-10. https://doi.org/10.1080/07391102.2020.1758788.

Boretti, A. and Banik, B.K. (2020). Intravenous vitamin C for reduction of cytokines storm in acute respxiratory distress syndrome. Pharma. Nutrition., 12:100190. https://doi.org/ 10.1016/j.phanu.2020.100190

Borthwick, L.A. (2016). The IL-1 cytokine family and its role in inflammation and fibrosis in the lung. Semin. Immunopathol., 38(4):517-534. doi: 10.1007/s00281-016-0559-z.

Brochot, A.; Guilbot, A.; Haddioui, L. and Roques, C. (2017). Antibacterial, antifungal, and antiviral effects of three essential oil blends. Microbiology Open, 6(4):e00459. https://doi.org/10.1002/mbo3.459

Busse, L.W.; Chow, J.H.; McCurdy, M.T. and Khanna, A.K. (2020). COVID-19 and the RAAS-a potential role for angiotensin II? Crit. Care, 24(1):136. doi: 10.1186/s13054-020-02862-1.

Canali, R., Natarelli, L., Leoni, G., Azzini, E., Comitato, R., Sancak, O., Barella, L. and Virgili, F. (2014). Vitamin C supplementation modulates gene expression in peripheral blood mononuclear cells specifically upon an inflammatory stimulus: A pilot study in healthy subjects. Genes Nutr., 9:390. doi: 10.1007/s12263-014-0390-x.

Carvalho J.T.G.; Schneider M.; Cuppari L.; Grabulosa C.C.; T Aoike, D.Q. Redublo, B.M.C.; Batista, M.; Cendoroglo, M.; Maria Moyses, R. and Dalboni, M.A. (2017). Cholecalciferol decreases inflammation and improves vitamin D regulatory enzymes in lymphocytes in the uremic environment: A randomized controlled pilot trial. PLoS ONE, pp:12 doi: 10.1371/journal.pone.0179540.

Cascella, M.; Rajnik, M.; Cuomo, A.; Scott, C.D. and Di Napoli, R. (2020) Features, evaluation, and treatment of coronavirus (COVID-19) In: StatPearls [Internet]. Treasure Island (FL): StatPearls Publishing. https://www.ncbi.nlm.nih.gov/books/NBK554776/.

Cecchini, R. and Cecchini, A.L. (2020). SARS-CoV-2 infection pathogenesis is related to oxidative stress as a response to aggression. Med. Hypotheses, 143:110102. https://doi.org/10.1016/ j.mehy.2020.110102

Chen, C.J.; Michaelis, M.; Hsu, H.K.; Tsai, C.C.; Yang, K.D.; Wu, Y.C.; Cinat Jr, J. and Doerr, H.W. (2008). Toona sinensis Roem tender leaf extract inhibits SARS coronavirus replication. J. Ethnopharmacol., 120(1): 108-111. https://doi.org/110.1016/j.jep.2008.1007. 1048

Chen, I.Y.; Moriyama, M.; Chang, M.F. and Ichinohe, T. (2019). Severe acute respiratory syndrome coronavirus viroporin 3 a activates the NLRP3 inflammasome. Front. Microbiol., 10:50. doi: 10.3389/ fmicb. 2019.00050

Chen, L.; Li, J.; Luo, C.; Liu, H.; Xu, W.; Chen, G.; Liew, O.W.; Zhu, W.; Puah, C.M. and Shen, X. (2006). Binding interaction of quercetin-3- $\beta$ galactoside and its synthetic derivatives with SARS-CoV 3CLpro: Structure-activity relationship studies reveal salient pharmacophore features. Bioorg. Med. Chem., 14(24):8295-8306. https://doi.org/ $8210.1016 /$ j.bmc.2006.8209.8014

Chen, L.; Liu, H.G.; Liu, W.; Liu, J.; Liu, K.; Shang, J. and Wei, S. (2020) Analysis of clinical features of 29 patients with 2019 novel coronavirus pneumonia. Zhonghua jie he he hu xi za zhi=Zhonghua jiehe he huxi zazhi= Chinese J. Tuberculosis Resp. Dis., 43:E005E005.

Cheng, P.W.; Ng, L.T.; Chiang, L.C. and Lin, C.C. (2006). Antiviral effects of saikosaponins on human coronavirus $229 \mathrm{E}$ in vitro. Clin. Exp. Pharmacol. Physiol., 33(7):612-616. https://doi.org/610.1111/ j.1440-1681.2006.04415.x
Cheng, R.Z. (2020). Can early and high intravenous dose of vitamin C prevent and treat coronavirus disease (COVID-19). Med. Drug. Discov., 5:100028. doi: 10.1016/j.medidd.2020.100028

Cheung, C.Y.; Poon, L.L.M.; Ng, I.H.Y.; Luk, W.; Sia, S.F. and Wu, M.H.S. (2005) Cytokine responses in severe acute respiratory syndrome coronavirusinfected macrophages in vitro: Possible relevance to pathogenesis. J. Virol., 79(12):7819-7826. doi: 10.1128/JVI.79.12.7819-7826.2005

Cho, J.K.; Curtis-Long, M.J.; Lee, K.H.; Kim, D.W.; Ryu, H.W.; Yuk, H.J. and Park, K.H. (2013). Geranylated flavonoids displaying SARS-CoV papain-like protease inhibition from the fruits of Paulownia tomentosa. Bioorg. Med. Chem., 21(11):3051-3057. https:// doi.org/3010.1016/j.bmc.2013.3003.3027

Chojnacka, K.; Witek-Krowiak, A.; Skrzypczak, D.; Mikula, K. and Młynarz, P. (2020). Phytochemicals containing biologically active polyphenols as an effective agent against Covid-19-inducing coronavirus. J. Functional. Foods, 73:104146. https://doi.org/ $10.1016 /$ j.jff.2020.104146

Conti, P.; Ronconi, G.; Caraffa, A.; Gallenga, C.; Ross, R.; Frydas, I. and Kritas, S. K. (2020). Induction of pro-inflammatory cytokines (IL-1 and IL-6) and lung inflammation by coronavirus-19 (COVI-19 or SARS-CoV-2): Anti-inflammatory strategies. J. Biol. Regul. Homeost. Agents., 34(2):327-331. doi: 10.23812/CONTI-E. PMID:32171193.

Cowan, M.M. (1999). Plant products as antimicrobial agents. Clin. Microbiol. Rev., 12:564-582. 0893-8512/99/\$04.0010

de la Fuente, M.; Hernanz, A.; Guayerbas, N.; Victor, V.M. and Arnalich, F. (2008). Vitamin $\mathrm{E}$ ingestion improves several immune functions in elderly men and women. Free Radic Res., 42:272-280. doi: 10.1080/10715760801898838.

Delgado-Roche, L. and Mesta, F. (2020). Oxidative stress as key player in severe acute respiratory syndrome coronavirus (SARS-CoV) infection. Arch. Med. Res., 51:384-387. doi: 10.1016/j.arcmed.2020.04.019.

di Mauro, G.; Scavone, C.; Rafaniello, C.; Rossi, F. and Capuano, A. (2020). SARS-CoV-2 infection: Response of human immune system and possible implications for the rapid test and treatment. Int. Immunopharmacol., 84:106519. https://doi.org/10.1016/j.intimp. 2020.106519

Dong, L.; Hu, S. and Gao, J. (2020a). Discovering drugs to treat coronavirus disease 2019 (COVID-19). Drug. Discov. Ther., 14(1):58-60. https:/ /doi.org/10.5582/ddt.2020. 01012 .

Dong, Y.; Mo, X.; Hu, Y.; Qi, X.; Jiang, F.; Jiang, Z. and Shilu Tong, S. (2020b). Epidemiological characteristics of 2143 pediatric patients with 2019 coronavirus disease in China. Pediatrics. Available from: https://dx.doi.org/10.1542/peds.2020-0702

Duntas, L.H. and Benvenga, S. (2015). Selenium: An element for life. Endocrine., 48(3):756-775. doi: 10.1007/s12020-014-0477-6.

Dutra, F.F. and Bozza, M.T. (2014). Heme on innate immunity and inflammation. Front. Pharmacol., 5:115. doi: 10.3389/fphar. 2014.00115

Dziri, S.; Casabianca, H.; Hanchi, B. and Hosni, K. (2014). Composition of garlic essential oil (Allium sativum L.) as influenced by drying method, J. Essent. Oil Res., 26(2):91-96. doi: 10.1080/ 10412905.2013 .868329

Edwards, M. R.; Bartlett, N. W.; Clarke, D.; Birrell, M.; Belvisi, M. and Johnston, S. L. (2009). Targeting the NF- $\mathrm{B}$ pathway in asthma and chronic obstructive pulmonary disease. Pharmacol. Ther., 121:1-13. doi: 10.1016/j.pharmthera.2008.09.003 
Fernandes, A.C.L.; Vale, A.J.M.; Guzen, F.P.; Pinheiro, F.I.; Cobucci, R.N. and de Azevedo, E.P. (2020). Therapeutic options against the new coronavirus: Updated clinical and laboratory evidences. Front. Med., 7:546. doi: 10.3389/fmed.2020.00546.

Fernández-Quintela, A.; Milton-Laskibar, I.; Trepiana, J.; Gómez-Zorita, S.; Kajarabille, N.; Léniz, A.; González, M. and Portillo, M.P. (2020). Key aspects in nutritional management of COVID-19 patients. J. Clin. Med., 9(8):E2589. https://doi.org/10.3390/jcm9082589.

Games, E.; Guerreiro, M.; Santana, F.R.; Pinheiro, N.M.; de Oliveira, E.A.; Lopes, F. D.; Olivo, C.R.; Tibério, I.F.; Martins, M.A.; Lago, J. H. and Prado C.M. (2016). Structurally related monoterpenes p-cymene, carvacrol and thymol isolated from essential oil from leaves of Lippia sidoides Cham. (Verbenaceae) protect mice against elastaseinduced emphysema. Molecules (Basel, Switzerland), 21(10):1390. https://doi.org/10.3390/molecules2 1101390

Gao, X.; Wilsgaard, T.; Jansen, E.H.; Holleczek, B.; Zhang, Y.; Xuan, Y.; Anusruti, A.; Brenner, H. and Schottker, B. (2019). Pre-diagnostic derivatives of reactive oxygen metabolites and the occurrence of lung, colorectal, breast and prostate cancer: An individual participant data meta-analysis of two large population-based studies. Int. J. Cancer, 145(1):49-57. doi: 10.1002/ijc. 32073 .

García, L.F. (2020). Immune response, inflammation, and the clinical spectrum of COVID-19. Front. Immunol., 11:1441. doi:10.3389/ fimmu.2020.01441

Gentile, D.; Patamia, V.; Scala, A.; Sciortino, M. T.; Piperno, A. and Rescifina, A. (2020). Putative inhibitors of SARS-CoV-2 main protease from a library of marine natural products: A virtual screening and molecular modeling study. Mar. Drugs, 18(4):225. https://doi.org/210.3390/ md18040225

Ghosh, R.; Chakraborty, A.; Biswas, A. and Chowdhuri, S. (2020). Evaluation of green tea polyphenols as novel corona virus (SARSCoV-2) main protease (Mpro) inhibitors-an in silico docking and molecular dynamics simulation study. J. Biomol. Struct. Dyn., pp:1-13. https://doi.org/10.1080/07391102.07392020.01779818

Gilling, D. H.; Kitajima, M.; Torrey, J. R. and Bright, K. R. (2014) Mechanisms of antiviral action of plant antimicrobials against murine norovirus. Appl. Environ. Microbiol., 80(16):4898-910. doi: 10.1128/AEM.00402-14.

Gombart, A.F.; Pierre, A. and Maggini, S. (2020). A review of micronutrients and the immune system-working in harmony to reduce the risk of infection. Nutrients., 12:236. doi: 10.3390/nu12010236

Hagen, T.M. (2003). Oxidative stress, redox imbalance, and the aging process. Antioxid. Redox Signal., 5:503-506. doi: 10.1089/ 152308603770310149 .

Halliwell, B. and Gutteridge, J.M. (1999). Free radicals in biology and medicine, third edition. Oxford University Press, Midsomer Norton, Avon, England.

Han, J.E.; Jones, J.L.; Tangpricha, V.; Brown, M.A.; Brown, L.A.S.; Hao, L.; Hebbar, G.; Lee, M.J.; Liu, S.; Ziegler, T.R. and Martin G.S. (2016) High dose vitamin D administration in ventilated intensive care unit patients: A pilot double blind randomized controlled trial. J. Clin. Transl. Endocrinol., 4:59-65. doi: 10.1016/j.jcte.2016.04.004.

Haslberger, A.G.; Jakob, U.; Hippe, B. and Karlic, H. (2020) Mechanisms of selected functional foods against viral infections with a view on COVID-19; Mini review. Funct. Foods. Health. Dis. 5(10):195-209. doi: 10.31989/ffhd.v10i5.707
Hati, S. and Bhattacharyya, S. (2020). Impact of thiol-disulfide balance on the binding of Covid-19 spike protein with angiotensin-converting enzyme 2 receptor. ACS Omega., 5(26):16292-16298. doi: 10.1021/ acsomega.0c02125

Hemilä, H. (1997). Vitamin C intake and susceptibility to pneumonia. Pediatr. Infect. Dis. J., 16:836-837. doi: 10.1097/00006454199709000-00003.

Ho, C. Y.; Cheng, Y. T.; Chau, C. F. and Yen, G. C. (2012). Effect of diallyl sulfide on in vitro and in vivo Nrf2-mediated pulmonic antioxidant enzyme expression via activation ERK/p38 signaling pathway. J. Agric. Food Chem., 60:100-107. https://doi.org/ $10.1021 / \mathrm{jf} 203800 \mathrm{~d}$

Ho, T.Y.; Wu, S.L.; Chen, J.C.; Li, C.C. and Hsiang, C.Y. (2007). Emodin blocks the SARS coronavirus spike protein and angiotensinconverting enzyme 2 interaction. Antiviral Res., 74(2):92-101. https://doi.org/110.1016/j.antiviral.2006.1004.1014

Hoffmann, M.; Kleine-Weber, H. and Pöhlmann, S.A. (2020). Multibasic cleavage site in the spike protein of SARS-CoV-2 Is essential for infection of human lung cells. Mol Cell., 78:779-784.e5. https:// doi.org/10.1016/j.molcel.2020.04.022

Hofmann, H. and Pöhlmann, S. (2004). Cellular entry of the SARS coronavirus. Trends Microbiol., 12:466-472. https://doi.org/ 10.1016/j.tim.2004.08.008

Holmes, K.V. (2003). SARS coronavirus: A new challenge for prevention and therapy. J. Clin. Invest., 111:1605-1609. doi: 10.1172/ JCI18819.

Hou, J.C. (1997). Inhibitory effect of selenite and other antioxidants on complement-mediated tissue injury in patients with epidemic hemorrhagic fever. Biol. Trace Elem. Res., 56:125-130. doi: 10.1007/BF02778988.

Huang, C.; Wang, Y.; Li, X.; Ren, L.; Zhao, J.; Hu, Y.; Zhang, L.; Fan, G.; Xu, J.; Gu, X.; Cheng, Z.; Yu, T.; Xia, J.; Wei, Y.; Wu, W.; Xie, X.; Yin, W.; Li, H.; Liu, M.; Xiao, Y.; Gao, H.; Guo, L.; Xie, J.; Wang, G.; Jiang, R.; Gao, Z.; Jin, Q.; Wang, J. and Cao, B. (2020). Clinical features of patients infected with 2019 novel coronavirus in Wuhan, China. The lancet., 395(10223):497-506. doi: 10.1016/S0140-6736(20)30183-5

Huang, H. and Wang, Y. (2017). The protective effect of cinnamaldehyde on lipopolysaccharide induced acute lung injury in mice. Cell. Mol. Biol. (Noisy-le-Grand, France), 63:58-63. https://doi.org/ $10.14715 / \mathrm{cmb} / 2017.63 .8 .13$

Huijskens, M.J.; Walczak, M.; Koller, N.; Briede, J.J.; Senden-Gijsbers, B.L.; Schnijderberg, M.C.; Bos, G.M. and Germeraad, W.T. (2014). Technical advance: Ascorbic acid induces development of double-positive T cells from human hematopoietic stem cells in the absence of stromal cells. J. Leukoc. Biol., 96:1165-1175. doi: 10.1189/ jlb.1TA0214-121RR.

Ilie, P.C.; Stefanescu, S. and Smith, L. (2020). The role of vitamin D in the prevention of coronavirus disease 2019 infection and mortality. Aging. Clin. Exp. Res., 32:1195-1198. doi: 10.1007/s40520-020-01570-8

Jayawardena, R.; Sooriyaarachchi, P.; Chourdakis, M.; Jeewandara, C. and Ranasinghe, P. (2020). Enhancing immunity in viral infections, with specialemphasis on COVID-19: A review. Diabetes. Metab. Syndr., 14:367-382. doi: $10.1016 /$ j.dsx.2020.04.015

Jeng, K.C.; Yang, C.S.; Siu, W.Y.; Tsai, Y.S.; Liao, W.J. and Kuo J.S. (1996) Supplementation with vitamins $\mathrm{C}$ and E enhances cytokine production by peripheral blood mononuclear cells in healthy adults. Am. J. Clin. Nutr., 64:960-965. doi: 10.1093/ajcn/64.6.960. 
Jo, S.; Kim, H.; Kim, S.; Shin, D. H. and Kim, M.S. (2019). Characteristics of flavonoids as potent MERS-CoV 3C-like protease inhibitors. Chem. Biol. Drug Des., 94(6):2023-2030. https://doi.org/2010.1111/ cbdd. 13604

Jo, S.; Kim, S.; Shin, D. H. and Kim, M.S. (2020). Inhibition of SARS-CoV 3CL protease by flavonoids. J. Enzyme Inhib. Med. Chem., 35(1) 145-151. https://doi.org/110.1080/14756366.14752019.11690480

Juergens, L.J.; Worth, H. and Juergens, U.R. (2020). New perspectives for muco-lytic, anti-inflammatory and adjunctive therapy with 1,8 cineole in COPD and asthma: Review on the new therapeutic approach. Adv. Therapy, 37:1737-1753. https://doi.org/10.1007/ s 12325-020-01279-0

Kaur, G.; Lungarella, G. and Rahman, I. (2020). SARS-CoV-2 COVID-19 susceptibility and lung inflammatory storm by smoking and vaping. J. Inflamm (Lond)., 17:21. doi: 10.1186/s12950-02000250-8.

Khan, A.A.; Khan, S.; Khan, U. and Das, K. (2020). The COVID-19 pandemic: A scoping review. Ann. of Phytomed., 9(1):18-26, doi: http://dx.doi.org/10.21276/ap.2020.9.1.3

Kim, D.W.; Seo, K.H.; Curtis-Long, M.J.; Oh, K.Y.; Oh, J.W.; Cho, J. K.; Lee, K.H. and Park, K.H. (2014). Phenolic phytochemical displaying SARS$\mathrm{CoV}$ papain-like protease inhibition from the seeds of Psoralea corylifolia. J. Enzyme Inhib. Med. Chem., 29(1):59-63. https:// doi.org/10.3109/14756366.14752012.1475359

Kim, Y.; Kim, H.; Bae, S.; Choi, J.; Lim, S. Y.; Lee, N.; Kong, J. M.; Hwang, Y.; Kang, J. S. and Lee, W. J. (2013). Vitamin C is an essential factor on the anti-viral immune responses through the production of interferon$\mathrm{a} / \mathrm{b}$ at the initial stage of influenza A virus (H3N2) infection. Immune Network, 13(2):70-74. doi: 10.4110/in.2013.13.2.70.

Krammer, F. (2020). SARS-CoV-2 vaccines in development. Nature, 586:516-527. https://doi.org/10.1038/s41586-020-2798-3

Kregel, K.C. and Zhang, H.J. (2007). An integrated view of oxidative stress in aging: Basic mechanisms, functional effects, and pathological considerations. Am. J. Physiol. Regul. Integr. Comp. Physiol. 292:R18-36. doi: 10.1152/ajpregu.00327.2006.

Kritas, S. K.; Ronconi, G.; Caraffa, A.; Gallenga, C. E.; Ross, R. and Conti, P. (2020). Mast cells contribute to coronavirus-induced inflammation: New anti-inflammatory strategy. J. Biol. Regul. Homeost. Agents., 34(1):9-14. doi: 10.23812/20-Editorial-Kritas

Kulkarni, S. A.; Nagarajan, S. K.; Ramesh, V.; Palaniyandi, V.; Selvam, S. P. and Madhavan, T. (2020). Computational evaluation of major components from plant essential oils as potent inhibitors of SARS-CoV-2 spike protein. J. Molec. Struct., 1221:128823. https://doi. org/10.1016/ j.molstruc.2020.128823

Lau, S.K.P.; Lau, C.C.Y.; Chan, K.-H.; Li, C.P.Y.; Chen H. and Jin D.Y. (2013) Delayed induction of proinflammatory cytokines and suppression of innate antiviral response by the novel Middle East respiratory syndrome coronavirus: Implications for pathogenesis and treatment. J. Gen. Virol., 94(Pt 12):2679-2690. doi: 10.1099/ vir.0.055533-0.

Lavillette, D.; Barbouche, R.; Yao, Y.; Boson, B.; Cosset, F.L.; Jones, I.M. and Fenouillet, E. (2006). Signifcant redox insensitivity of the functions of the SARS-CoV spike glycoprotein: comparison with HIV envelope. J. Biol. Chem., 281(14):9200-9204. doi: 10.1074/ jbc.M512529200.
Law, H.K.W.; Cheung, C.Y.; Ng, H.Y.; Sia, S.F.; Chan, Y.O. and Luk, W. (2005). Chemokine up-regulation in SARS-coronavirus-infected, monocytederived human dendritic cells. Blood., 106(7):2366-2374. doi: 10.1182/blood-2004-10-4166.

Lei, J.; Kusov, Y. and Hilgenfeld, R. (2018). Nsp3 of coronaviruses: Structures and functions of a large multi-domain protein. Antiviral Res., 149:58-74. https://doi.org/10.1016/j.antiviral. 2017.11.001

Letko, M. Marzi, A. Munster, V. (2020). Functional assessment of cell entry and receptor usage for SARS-CoV-2 and other lineage B betacoronaviruses. Nat. Microbiol., 5:562-569.

Li, S.Y.; Chen, C.; Zhang, H.Q.; Guo, H.Y.; Wang, H.; Wang, L.; Zhang, X.; Hua, S.N.; Yu, J. and Xiao, P.G. (2005). Identification of natural compounds with antiviral activities against SARS-associated coronavirus. Antiviral Res., 67(1):18-23. https://doi.org/10.1016/j.antiviral.2005.1002.1007

Liao, M.; Liu, Y.; Yuan, J.; Wen, Y.; Xu, G.; Zhao, J.; Cheng, L.; Li, J.; Wang, X.; Wang, F.; Liu, L.; Amit, I.; Zhang, S. and Zhang, Z. (2020). The landscape of lung bronchoalveolar immune cells in COVID-19 revealed by single-cell RNA sequencing. Nat. Med., 26(6):842-844. doi: 10.1038/s41591-020-0901-9.

Lin, C.W.; K.H.; Lin, T.H.; Hsieh, S.Y.; Shiu, and Li, J.Y. (2006). Severe acute respiratory syndrome coronavirus $3 \mathrm{C}$-like protease-induced apoptosis. FEMS Immunol. Med. Microbiol., 46:375-380. doi: 10.1111/j.1574-695X.2006.00045.x.

Lin, C.W.; Tsai, F.J.; Tsai, C.H.; Lai, C.C.; Wan, L.; Ho, T.Y.; Hsieh, C.C. and Chao, P.D.L. (2005). Anti-SARS coronavirus 3C-like protease effects of Isatis indigotica root and plant-derived phenolic compounds. Antiviral Res., 68(1):36-42. https://doi.org/10.1016/j.antiviral.2005.1007.1002

Lingeswaran, M.; Goyal, T.; Ghosh, R.; Suri, S.; Mitra, P.; Misra, S. and Sharma, P. (2020). Inflammation, immunity and immunogenetics in COVID-19: A narrative review. Indian. J. Clin. Biochem., 35(3):260-273. https://doi.org/10.1007/s12291-020-00897-3

Lippi, G. and Mattiuzzi, C. (2020). Hemoglobin value may be decreased in patients with severe coronavirus disease. Hematol. Transfus. Cell Ther., 42(2):116-117. https://doi.org/10.1016/j.htct.2020.03.001

Liu P.T.; Stenger S.; Tang D.H. and Modlin R.L. (2007). Cutting edge: Vitamin D-mediated human antimicrobial activity against Mycobacterium tuberculosis is dependent on the induction of cathelicidin. J. Immunol., 179:2060-2063. doi: 10.4049/jimmunol. 179.4.2060.

Liu, K.; Chen, Y.; Lin, R. and Han, K. (2020). Clinical features of COVID-19 in elderly patients: A comparison with young and middle-aged patients. J. Infect., 80:e14-e18. doi: 10.1016/j.jinf.2020.03.005

Liugan, M. and Carr, A.C. (2019). Vitamin C and neutrophil function: Findings from randomized controlled trials. Nutrients., 11(9). doi: $10.3390 / \mathrm{nu} 11092102$

Ma, L. and Yao, L. (2020). Antiviral effects of plant-derived essential oils and their components: an updated review. Molecules., 25:2627. doi: $10.3390 /$ molecules 25112627

Mani, J.S.; Johnson, J.B.; Steel, J.C.; Broszczak, D.A.; Neilsen, P.M.; Walsh, K.B. and Naiker, M. (2020). Natural product-derived phytochemicals as potential agents against coronaviruses: A review. Virus Res., 284:197989. doi: $10.1016 /$ j.virusres.2020.197989

Marchingo, J.M.; Sinclair, L.V.; Howden, A.J. and Cantrell, D.A. (2020) Quantitative analysis of how Myc controls $\mathrm{T}$ cell proteomes and metabolic pathways during $\mathrm{T}$ cell activation. Elife., 9:e53725. doi: $10.7554 /$ eLife. 53725 
McCarty, M.F. and DiNicolantonio, J.J. (2020). Nutraceuticals have potential for boosting the type 1 interferon response to RNA viruses including influenza and coronavirus. Prog. Cardiovasc. Dis., 63:383-385. doi: 10.1016/j.pcad.2020.02.007

McCord, J. M.; Hybertson, B. M.; Cota-Gomez, A. and Gao, B. (2020). $\mathrm{Nrf} 2$ activator $\mathrm{PB} 125^{\circledR}$ as a potential therapeutic agent against COVID-19. BioRxiv: The preprint server for biology, 2020.05. 16.099788. https://doi.org/10.1101/2020.05.16.099788

Mediouni, S.; Jablonski, J. A.; Tsuda, S.; Barsamian, A.; Kessing, C.; Richard, A.; Biswas, A.; Toledo, F.; Andrade, V. M.; Even, Y.; Stevenson, M.; Tellinghuisen, T.; Choe, H.; Cameron, M.; Bannister, T. D. and Valente, S. T. (2020). Oregano oil and its principal component carvacrol inhibit HIV-1 fusion into target cells. J. Virol., 94(15):e00147-20. https:/ /doi.org/10.1128/jvi.00147-20

Millet, J.K. and Whittaker, G.R. (2014). Host cell entry of Middle East respiratory syndrome coronavirus after two-step, furin-mediated activation of the spike protein. Proc. Natl. Acad. Sci. USA, 111:15214-15219. https://doi.org/10.1073/pnas.1407087111

Moriguchi, S. and Muraga, M. (2000). Vitamin E and immunity. Vitam. Horm., 59:305-336. doi: 10.1016/s0083-6729(00)59011-6.

Muscogiuri, G.; Barrea, L.; Savastano, S. and Colao, A. (2020). Nutritional recommendations for CoVID-19 quarantine. Eur. J. Clin. Nutr., 74:850-851. https://doi.org/10.1038/s41430-020-0635-2

Narkhede, R. R.; Pise, A. V.; Cheke, R. S. and Shinde, S. D. (2020). Recognition of natural products as potential inhibitors of COVID-19 main protease (Mpro): In silico evidences. Nat. Prod. Bioprospect., 10(5):297-306. https://doi.org/310.1007/s13659-13020-0025313651

Nguefack, J.; Budde, B.B. and Jakobsen, M. (2004). Five essential oils from aromatic plants of Cameroon: Their antibacterial activity and ability to permeabilize the cytoplasmic membrane of Listeria innocua examined by flow cytometry. Lett. Appl. Microbiol., 39:395-400. doi: 10.1111/j.1472-765X.2004.01587.x.

Nguyen, T.T.H.; Woo, H.J.; Kang, H.K.; Kim, Y.M.; Kim, D.W.; Ahn, S.A.; Xia, Y. and Kim, D. (2012). Flavonoid-mediated inhibition of SARS coronavirus $3 \mathrm{C}$-like protease expressed in Pichia pastoris. Biotechnol. Lett., 34(5):831-838. https://doi.org/810.1007/ s 10529-10011-10845-10528

Paniri, A. and Akhavan-Niaki, H. (2020). Emerging role of IL-6 and NLRP3 inflammasome as potential therapeutic targets to combat COVID-19: Role of lncRNAs in cytokine storm modulation. Life. Sci., 257:118114. doi:10.1016/j.1fs.2020.118114

Park, J.; Lee, S. J.; Kim, K. H.; Kwon, K. W. and Jeong, J.W. (2016). Estimating thermal performance and energy saving potential of residential buildings using utility bills. Energy. Build., 110:23-30. https://doi.org/10.1016/j.enbuild.2015.1010.1038

Park, J.Y.; Jeong, H.J.; Kim, J.H.; Kim, Y.M.; Park, S.J.; Kim, D.; Park, K.H.; Lee, W.S. and Ryu, Y.B. (2012a). Diarylheptanoids from Alnus japonica inhibit papain-like protease of severe acute respiratory syndrome coronavirus. Biol. Pharm. Bull., 35(11):2036-2042. https://doi.org/2010.1248/bpb.b2012-00623

Park, J.Y.; Kim, J. H.; Kim, Y. M.; Jeong, H. J.; Kim, D. W.; Park, K. H.; Kwon, H. J.; Park, S. J.; Lee, W. S. and Ryu, Y. B. (2012b). Tanshinones as selective and slow-binding inhibitors for SARS-CoV cysteine proteases. Bioorganic. Med. Chem., 20(19):5928-5935. https:// doi.org/5910.1016/j.bmc.2012.5907.5038
Park, J. Y.; Kim, J. H.; Kwon, J. M.; Kwon, H. J.; Jeong, H. J.; Kim, Y. M.; Kim, D.; Lee, W. S. and Ryu, Y. B. (2013). Dieckol, a SARS-CoV 3CLpro inhibitor, isolated from the edible brown algae Ecklonia cava. Bioorganic. Med. Chem., 21(13):3730-3737. https://doi.org/ 3710.1016/j.bmc.2013.3704.3026

Park, J. Y.; Yuk, H. J.; Ryu, H. W.; Lim, S. H.; Kim, K. S.; Park, K. H.; Ryu, Y. B. and Lee, W. S. (2017). Evaluation of polyphenols from Broussonetia papyrifera as coronavirus protease inhibitors. J. Enzyme Inhib. Med. Chem., 32(1):504-512. https://doi.org/ $510.1080 / 14756366.14752016 .11265519$

Perrotta, F.; Corbi, G.; Mazzeo, G.; Boccia, M.; Aronne, L.; D’Agnano, V.; Komici, K.; Mazzarella, G.; Parrella, R. and Bianco, A. (2020). COVID-19 and the elderly: Insights into pathogenesis and clinica decision making. Aging. Clin. Exp. Res., pp:1-10. https://doi.org/10.1007 /s40520-020-01631-y.

Prabhu, K.S. and Lei, X.G. (2016). Selenium. Adv. Nutr., 7(2):415-417. doi: $10.3945 /$ an. 115.010785 .

Prasad, A.S. (2013). Discovery of human zinc deficiency: its impact on human health and disease. Advances in Nutrition, 4:176-190. doi: 10.3945/an.112.003210

Pretorius, E.; Bester, J.; Vermeulen, N. and Lipinski, B. (2013). Oxidation inhibits iron-induced blood coagulation. Current. Drug. targets, 14(1):13-19. doi: 10.2174/1389450111314010003

Read, S.A.; O'Connor, K.S.; Suppiah, V.; Ahlenstiel, C.L.E.; Obeid, S.; Cook, K.M.; Cunningham, A.; Douglas, M.W.; Hogg, P.J.; Booth, D.; George, J. and Ahlenstiel, G. (2017). Zinc is a potent and specific inhibitor of IFN- $\lambda 3$ signalling. Nat. Commun., 8:15245. doi: 10.1038/ ncomms 15245 .

Read, S.A.; Obeid, S.; Ahlenstiel, C. and Ahlenstiel, G. (2019). The role of zinc in antiviral immunity. Adv. Nutr., 10(4):696-710. doi: 10.1093/ advances/nmz013.

Reichling, J.; Suschke, U.; Schneele, J. and Geiss, H.K. (2006). Antibacterial activity and irritation potential of selected essential oil components: Structure-activity relationship. Nat. Prod. Comm., 1:1003-1012. https://doi.org/10.1177/1934578X0600101116

Roh, C. (2012). A facile inhibitor screening of SARS coronavirus N protein using nanoparticle-based RNA oligonucleotide. Int. J. Nanomedicine, 7:2173-2179. https://doi.org/2110.2147/IJN.S31379

Rozza, A.L.; Meira de Faria, F.; Souza Brito, A.R. and Pellizzon, C.H. (2014). The gastroprotective effect of menthol: Involvement of antiapop-totic, antioxidant and anti-inflammatory activities. PLoS ONE, 9:e86686. https://doi.org/10.1371/journal.pone.0086686

Ryu, Y. B.; Jeong, H. J.; Kim, J. H.; Kim, Y. M.; Park, J.-Y.; Kim, D.; Naguyen, T. T. H.; Park, S.J.; Chang, J. S. and Park, K. H. (2010a). Biflavonoids from Torreya nucifera displaying SARS-CoV 3CLpro inhibition. Bioorganic. Med. Chem., 18(22):7940-7947. https://doi.org/ 7910.1016/j.bmc.2010.7909.7035

Ryu, Y. B.; Park, S.J.; Kim, Y. M.; Lee, J.-Y.; Seo, W. D.; Chang, J. S.; Park, K. H.; Rho, M.C. and Lee, W. S. (2010b). SARS-CoV 3CLpro inhibitory effects of quinone-methide triterpenes from Tripterygium regelii. Bioorganic. Med. Chem. Lett., 20(6):1873-1876. https://doi.org/ $1810.1016 /$ j.bmcl.2010.1801.1152

Sadlon, A. E. and Lamson, D. W. (2010). Immune-modifying and antimicrobial effects of eucalyptus oil and simple inhalation devices. Altern. Med. Rev. J. Clin. Ther., 15:33-47 
Sarkar, C.; Mondal, M.; Torequl Islam, M.; Martorell, M.; Oana Docea, A.; Maroyi, A.; Sharifi-Rad J. and Calina, D. (2020). Potential therapeutic options for COVID-19: Current status, challenges and future perspectives. Front. Pharmacol., 11:572870. doi: 10.3389/ fphar.2020.572870

Schnitzler, P.; Astani, A. and Reichling, J. (2010). Antiviral effects of plantderived essential oils and pure oil components. Lipids. Essent. Oils. Antimicrob. Agents, pp:239-254. https://doi.org/10.1002/ 9780470976623.ch 10

Schöttker, B.; Brenner, H.; Jansen, E.H.; Gardiner, J.; Peasey, A.; Kubinova, R.; Pajak, A.; Topor-Madry, R.; Tamosiunas, A.; Saum, K.U.; Holleczek, B.; Pikhart, H. and Bobak, M. (2015). Evidence for the free radical/ oxidative stress theory of ageing from the CHANCES consortium: a meta-analysis of individual participant data. BMC Med., 13(1):300. doi: 10.1186/s12916-015-0537-7.

Schöttker, B.; Saum, K.U.; Jansen, E.H.; Holleczek, B. and Brenner, H. (2016). Associations of metabolic, inflammatory and oxidative stress markers with total morbidity and multi-morbidity in a large cohort of older German adults. Age. Ageing, 45(1):127-135. doi: 10.1093/ageing/afv159.

Schuhmacher, A.; Reichling, J. and Schnitzler, P. (2003). Virucidal effect of peppermint oil on the enveloped viruses Herpes simplex virus type 1 and type 2 in vitro. Phytomedicine, 10:504-510. doi: $10.1078 / 094471103322331467$

Sekiou, O.; Bouziane, I.; Bouslama, Z. and Djemel, A. (2020). In silico identification of potent inhibitors of COVID-19 main protease (Mpro) and angiotensin converting enzyme 2 (ACE2) from natural products: Quercetin,hispidulin, and cirsimaritin exhibited better potential inhibition than hydroxy-chloroquine against COVID-19 main protease active site and ACE2. ChemRxiv., pp:1-22. https:/ /doi.org/10.26434/chemrxiv.12181404.v1

Senthil Kumar, K. J.; Gokila Vani, M.; Wang, C. S.; Chen, C. C.; Chen, Y. C.; Lu, L. P.; Huang, C. H.; Lai, C. S. and Wang, S. Y. (2020). Geranium and lemon essential oils and their active compounds downregulate angiotensin-converting enzyme 2 (ACE2), a SARS-CoV-2 spike receptor-binding domain, in epithelial cells. Plants (Basel, Switzerland),, 9(6):770. https://doi.org/10.3390/plants9060770

Shankar, A.H. and Prasad, A.S. (1998). Zinc and immune function: The biological basis of altered resistance to infection. Am. J. Clin. Nutr., 68(2 Suppl):447S-463S. doi: 10.1093/ajen/68.2.447S

Shao, H.W.; Lan, D.M.; Duan, Z.H.; Liu, Z.H.; Min, J.; Zhang, L.C.; Huang, J.; Su, J.; Chen, S.W. and Xu, A.L. (2006). Upregulation of mitochondrial gene expression in PBMC from convalescent SARS patients. J. Clin. Immunol., 26(6):546-554. doi: 10.1007/s10875006-9046-y

Sharma, A. D. and Kaur, I. (2020a). Jensenone from eucalyptus essential oil as a potential inhibitor of COVID-19 corona virus infection. Res. Rev. Biotech. Biosci., 7:59-66. doi:http://doi.org/10.5281/ zenodo. 3748477

Sharma, A. D. and Kaur, I. (2020b). Eucalyptol (1,8 cineole) from eucalyptus essential oil a potential inhibitor of COVID-19 corona virus infection by molecular docking studies. Preprints, pp:2020030455. doi: 10.20944 /preprints202003.0455.v1

Shen, Y. C.; Wang, L. T.; Khalil, A. T.; Chiang, L. C. and Cheng, P. W. (2005). Bioactive pyranoxanthones from the roots of Calophyllum blancoi. Chem. Pharm. Bull., 53(2):244-247. https://doi.org/ $210.1248 / \mathrm{cpb} .1253 .1244$

Shurin, M. R.; Morris, A.; Wells, A. and Wheeler, S. E. (2020). Assessing immune response to SARS-CoV-2 infection. Immuno Targets and Therapy, 9:111-114. https://doi.org/10.2147/ ITT.S264138
Siddiqui, Y. M.; Ettayebi, M.; Haddad, A. M. and Al-Ahdal, M. N. (1996). Effect of essential oils on the enveloped viruses: Antiviral activity of oregano and clove oils on Herpes simplex virus type 1 and Newcastle Disease Virus Med. Sci. Res., 24:185-186.

Silva, J.; Figueiredo, P.; Byler, K. G. and Setzer, W. N. (2020). Essential oils as antiviral agents. Potential of essential oils to treat SARS-CoV-2 infection: An in silico investigation. Int. J. Mol. Sci., 21(10): 3426. https://doi.org/10.3390/ijms21103426

Simmons, G.; Reeves, J.D.; Rennekamp, A.J.; Amberg, S.M.; Piefer, A.J. and Bates, P. (2004). Characterization of severe acute respiratory syndrome-associated coronavirus (SARS-CoV) spike glycoproteinmediated viral entry. Proc. Natl. Acad. Sci. USA, 101:4240-4245. https://doi.org/10.1073/pnas.0306446101

Singh, M. and Das, R.R. (2013). Zinc for the common cold. Cochrane Database Syst. Rev., pp:CD001364. https://doi.org/10.1002/ 14651858.CD001364.pub4

Singh, P.; Tripathi, M. K.; Yasir, M.; Khare, R.; Tripathi, M. K. and Shrivastava, R. (2020). Potential inhibitors for SARS-CoV-2 and functional food components as nutritional supplement for COVID-19: A review. Plant Foods Hum. Nutr., 75:458-466. https://doi.org/410.1007/ s 11130-11020-00861-11139

Smith, E.M.; Jones, J.L.; Han, J.E.; Alvarez, J.A.; Sloan, J.H.; Konrad, R.J.; Zughaier, S.M.; Martin, G.S.; Ziegler, T.R. and Tangpricha, V. (2018). High-Dose vitamin D3 administration is associated with increases in hemoglobin concentrations in mechanically ventilated critically ill adults: A pilot double-blind, randomized, placebo-controlled trial. JPEN J. Parenter. Enter. Nutr., 42:87-94. doi: 10.1177/ 0148607116678197.

Song, H.C.; Seo, M.Y.; Stadler, K.; Yoo, B.J.; Choo, Q.L.; Coates, S.R.; Uematsu, Y.; Harada, T.; Greer, C.E.; Polo, J.M.; Pileri, P.; Eickmann, M.; Rappuoli, R.; Abrignani, S.; Houghton, M. and Han, J.H. (2004). Synthesis and characterization of a native, oligomeric form of recombinant severe acute respiratory syndrome coronavirus spike glycoprotein. Journal of Virology, 78(19):10328-10335. https://doi.org/10. 1128/ JVI.78.19.10328-10335.2004

Song, W.; Gui, M.; Wang, X. and Xiang, Y. (2018). Cryo-EM structure of the SARS coronavirus spike glycoprotein in complex with its host cell receptor ACE2. PLoS Pathog., 14(8):e1007236. https://doi.org/ 10.1371/journal.ppat.1007236

Song, Y. H.; Kim, D. W.; Curtis-Long, M. J.; Yuk, H. J.; Wang, Y.; Zhuang, N.; Lee, K. H.; Jeon, K. S. and Park, K. H. (2014). Papain-like protease (PLpro) inhibitory effects of cinnamic amides from Tribulus terrestris fruits. Biol. Pharm. Bull., 37(6):1021-1028. https://doi.org/ 1010.1248/bpb.b1014-00026.

Steinbrenner, H.; Al-Quraishy, S.; Dkhil, M.A.; Wunderlich, F. and Sies, H. (2015). Dietary selenium in adjuvant therapy of viral and bacterial infections. Adv. Nutr., 6:73-82. doi: 10.3945/an.114.007575.

Subbarao, K. and Mahanty, S. (2020). Respiratory virus infections: Understanding COVID-19. Immunity., 52:905-909. doi: 10.1016/ j.immuni.2020.05.004

Suhail, S.; Zajac, J.; Fossum, C.; Lowater, H.; McCracken, C.; Severson, N.; Laatsch, B.; Narkiewicz Jodko, A.; Johnson, B.; Liebau, J.; Bhattacharyya, S. and Hati, S. (2020). Role of oxidative stress on SARS COV (SARS) and SARS CoV 2 (COVID 19) infection: A review. The Protein Journal. https://doi.org/10.1007/s10930-020-09935-8

Tay, M. Z.; Poh, C. M.; Rénia, L.; MacAry, P.A. and Ng, L.F. (2020). The trinity of COVID-19: Immunity, inflammation and intervention. Nat. Rev. Immunol., 20:363-374. https://doi.org/10.1038/s41577020-0311-8 
Taylor, E.W.; Ruzicka, J.A.; Premadasa, L. and Zhao, L. (2016). Cellular selenoprotein mRNA tethering via antisense Interactions with ebola and HIV-1 mRNAs may impact host selenium biochemistry. Curr. Top. Med. Chem., 16:1530-1535. doi: 10.2174/1568026615 666150915121633 .

Thuy, B. T. P.; My, T. T. A.; Hai, N. T. T.; Hieu, L. T.; Hoa, T. T.; Thi Phuong Loan, H.; Triet, N. T.; Anh, T. T. V.; Quy, P. T.; Tat, P. V.; Hue, N. V.; Duong Tuan Quang, D. T.; Trung, N. T.; Tung, V. T.; Huynh, L. K. and Nguyen Thi Ai Nhung, N. T. A. (2020): Investigation into SARS-CoV 2 resistance of compounds in garlic essential oil. ACS Omega., 5:8312-8320. https://doi.org/10.1021/acsomega.0c00772

Tok, T. T. and Tatar, G. (2017). Structures and functions of coronavirus proteins: Molecular modeling of viral nucleoprotein. Int. J. Virol. Infect. Dis., 2:001-007.

Tutunchi, H.; Naeini, F.; Ostadrahimi, A. and Hosseinzadeh-Attar, M. J. (2020). Naringenin, a flavanone with antiviral and anti-inflammatory effects: A promising treatment strategy against COVID-19. Phytother. Res., pp:1-11. https://doi.org/10.1002/ptr.6781

Uchide, N.; Ohyama, K.; Bessho, T.; Yuan, B. and Yamakawa, T. (2002) Effect of antioxidants on apoptosis induced by influenza virus infection: Inhibition of viral gene replication and transcription with pyrrolidine dithiocarbamate. Antiviral. Res., 56:207-217. doi: $10.1016 / \mathrm{s} 0166-3542(02) 00109-2$.

Valavanidis, A.; Vlachogianni, T.; Fiotakis, K. and Loridas, S. (2013). Pulmonary oxidative stress, inflammation and cancer: Respirable particulate matter, fibrous dusts and ozone as major causes of lung carcinogenesis through reactive oxygen species mechanisms. Int J. Environ. Res. Public Health, 10:3886-3907. doi: 10.3390/ ijerph 10093886 .

Weiss, S.R. and Navas-Martin, S. (2005). Coronavirus pathogenesis and the emerging pathogen severe acute respiratory syndrome coronavirus Microbiol. Mol. Biol. Rev., 69(4):635-664. 10.1128/MMBR. 69.4.635-664.2005.

White J.H. (2010). Vitamin D as an inducer of cathelicidin antimicrobia peptide expression: Past, present and future. J. Steroid Biochem. Mol. Biol., 121:234-238. doi: 10.1016/j.jsbmb. 2010.03.034

Wink, M. (2020). Potential of DNA intercalating alkaloids and other plant secondary metabolites against SARS-CoV-2 causing COVID-19. Diversity, 12:175. https://doi.org/10.3390/d12050175

Wintergerst, E.S.; Maggini, S. and Hornig, D.H. (2007). Contribution of selected vitamins and trace elements to immune function. Ann. Nutr. Metab., 51(4):301-323. doi: 10.1159/000107673

Wu, C.; Liu, Y.; Yang, Y.; Zhang, P.; Zhong, W.; Wang, Y.; Wang, Q.; Xu, Y.; Li, M. and Li, X. (2020). Analysis of therapeutic targets for SARSCoV-2 and discovery of potential drugs by computational methods. Acta Pharm. Sin. B., 10(5):766-788. https://doi.org/710.1016/ j.apsb.2020.1002.1008

Xie, Z.; Chen, J.; Zheng, C.; Wu, J.; Cheng, Y.; Zhu, S.; Lin, C.; Cao, Q.; Zhu, J. and Jin, T. (2017). 1,25-dihydroxyvitamin D3-induced dendritic cells suppress experimental autoimmune encephalomyelitis by increasing proportions of the regulatory lymphocytes and reducing $\mathrm{T}$ helper type 1 and type 17 cells. Immunology., 152:414-424. doi: 10.1111/ imm. 12776.
Xiong, Y.; Liu, Y.; Cao, L.; Wang, D.; Guo, M.; Jiang, A.; Guo, D.; Hu, W.; Yang, J.; Tang, Z.; Wu, H.; Lin, Y.; Zhang, M.; Zhang, Q.; Shi, M.; Liu, Y.; Zhou, Y.; Lan, K. and Chen, Y. (2020). Transcriptomic characteristics of bronchoalveolar lavage fluid and peripheral blood mononuclear cells in COVID-19 patients. Emerg. Microbes. Infect., 9(1):761770. https://doi.org/10.1080/22221751.2020.1747363

Xu, J.; Zhou, F.; Ji, BP.; Pei, RS. and Xu, N. (2008). The antibacterial mechanism of carvacrol and thymol against Escherichia coli. Lett. Appl. Microbiol., 47:174-179. doi: 10.1111/j.1472-765X.2008. 02407.x.

Xue, J.; Moyer, A.; Peng, B.; Wu, J.; Hannafon, B.N. and Ding, W.Q. (2014). Chloroquine is a zinc ionophore. PLoS. ONE, 9:e109180. doi: 10.1371/journal.pone.0109180

Yang, T.C.; Lai, C.C.; Shiu, S.L.; Chuang, P.H.; Tzou, B.C.; Lin, Y.Y.; Tsai, F.J. and Lin, C.W. (2010). Japanese encephalitis virus down-regulates thioredoxin and induces ROS-mediated ASK1-ERK/p38 MAPK activation in human promonocyte cells. Microbes. Infect., 12: 643-651. doi: 10.1016/j.micinf.2010.04.007.

Yesudhas, D.; Srivastava, A. and Gromiha, M.M. (2020). COVID 19 outbreak: History, mechanism, transmission, structural studies and therapeutics. Infection. https://doi.org/10.1007/s 15010-020-01516-2

Yi, L.; Li, Z.; Yuan, K.; Qu, X.; Chen, J.; Wang, G.; Zhang, H.; Luo, H.; Zhu, L. and Jiang, P. (2004). Small molecules blocking the entry of severe acute respiratory syndrome coronavirus into host cells. J. Virol., 78(20):11334-11339. https://doi.org/11310.11128/JVI.11378. 11320.11334-11339.12004

Yu, M. S.; Lee, J.; Lee, J. M.; Kim, Y.; Chin, Y. W.; Jee, J. G.; Keum, Y. S. and Jeong, Y. J. (2012). Identification of myricetin and scutellarein as novel chemical inhibitors of the SARS coronavirus helicase, nsP13. Bioorg. Med. Chem. Lett., 22(12):4049-4054. https://doi.org/ $4010.1016 / \mathrm{j} . \mathrm{bmcl} .2012 .4004 .4081$

Zdrenghea, M.T.; Makrinioti, H.; Bagacean, C.; Bush, A.; Johnston, S.L. and Stanciu L.A. (2017). Vitamin D modulation of innate immune responses to respiratory viral infections. Rev. Med. Virol., 27(1). doi: $10.1002 /$ rmv. 1909 .

Zhang, J.; Taylor, E.W.; Bennett, K.; Saad, R. and Rayman, M.P. (2020). Association between regional selenium status and reported outcome of COVID-19 cases in China. Am. J. Clin. Nutr., 111:1297-1299. https://doi.org/10.1093/ajcn/nqaa095

Zhang, L. and Liu, Y. (2020). Potential interventions for novel coronavirus in China: A systematic review. J. Med. Virol., 92:479-490. doi: 10.1002/jmv. 25707

Zheng, Y.Y.; Ma, Y.T.; Zhang, J.Y. and Xie, X. (2020). COVID-19 and the cardiovascular system. Nat. Rev. Cardiol., 17:259-260. https:// doi.org/10.1038/s41569-020-0360-5

Zhou, Z.; Ren, L.; Zhang, L.; Zhong, J.; Xiao, Y.; Jia, Z.; Guo, L.; Yang, J.; Wang, C.; Jiang, S.; Yang, D.; Zhang, G.; Li, H.; Chen, F.; Xu, Y.; Chen, M.; Gao, Z.; Dong, J.; Liu, B.; Zhang, X.; Wang, W.; He, K.; Jin, Q.; Li, M. and Wang, J. (2020). Overly exuberant innate immune response to SARS-CoV-2 infection. Cell. Host. Microbe. https://doi.org/ $10.2139 /$ ssrn. 3551623 .

Zhu, N.; Zhang, D.; Wang, W.; Li, X.; Yang, B.; Song, J.; Zhao, X.; Huang, B.; Shi, W.; Lu, R.; Niu, P.; Zhan, F.; Ma, X.; Wang, D.; Xu, W.; Wu, G.; Gao, G. F. and Tan, W. (2020). A novel coronavirus from patients with pneumonia in China. N. Engl. J. Med., 382(8):727-733. doi: 10.1056/NEJMoa2001017.

Citation Yuva Bellik, Mostapha Bachir-Bey, Wided Fatmi, Mokhtaria Kouidri, Yasmina Souagui and Sidi Mohammed Ammar Selles (2020). Micronutrients and phytochemicals against COVID-19: Mechanism and molecular targets. Ann. Phytomed., 9(2):15-29. http://dx.doi.org/10.21276/ap.2020.9.2.3 